Boston University School of Law

Scholarly Commons at Boston University School of Law

Faculty Scholarship

$1-2008$

Clear Notice for Conditions on Spending, Unclear Implications for States in Federal Healthcare Programs

Nicole Huberfeld

Follow this and additional works at: https://scholarship.law.bu.edu/faculty_scholarship

Part of the Health Law and Policy Commons 


\title{
CLEAR NOTICE FOR CONDITIONS ON SPENDING, UNCLEAR IMPLICATIONS FOR STATES IN FEDERAL HEALTHCARE PROGRAMS ${ }^{\circ}$
}

\author{
NICOLE HUBERFELD ${ }^{* *}$
}

This Article explores Arlington Central School District Board of Education v. Murphy, a decision rendered by the first Roberts Court that may become a benchmark for Spending Clause jurisprudence. The majority in Arlington, led by Justice Alito, adopted the standard for constitutional conditions on spending that had been the dissenting view for years during the Rehnquist Court. More specifically, under the Pennhurst and Dole regime, the Court required Congress to provide "adequate" notice of conditions on spending, which seemed to be sufficient for the clear statement rule the Court (through Justice O'Connor) was seeking to institute. Arlington refashioned the foundational clear statement rule to a "clear notice" standard that requires more specific statutory language from Congress and that is particularly attuned to the state's viewpoint. This analytical shift may narrow Congress's ability to place conditions on federal spending, yet it fails to acknowledge the overlap between unambiguous conditions and coercing states, which this Article explores in the context of federal healthcare programs. These broad implications are focused by the example of the Clawback Provision, a section of the Medicare Prescription Drug, Improvement, and Modernization Act of 2003 that placed a new condition on states' receipt of Medicaid funds. The Clawback Provision shifts the administrative burden of pharmaceuticals for people enrolled in both Medicare and Medicaid (dual eligibles) to Medicare, while requiring the states to continue to pay for the cost of the drugs for the foreseeable future. (The Clawback Provision has been challenged by a number of states, but the cases remain unresolved.) Because of the Clawback Provision, states must fund the Medicare drug benefit for dual eligibles or face a total loss of Medicaid funds, which prevents states from choosing whether to provide a drug benefit to these Medicaid beneficiaries.

* Copyright (ㅇ 2008 by Nicole Huberfeld.

** Assistant Professor of Law, University of Kentucky College of Law. Thanks to Lori Ringhand, Charles Sullivan, Carl Coleman, and Elizabeth Weeks for comments and insights. Many thanks to Ross Ewing for diligent research assistance. Thanks always, DT. 
Arlington seems to require language for conditions on spending that could not have been anticipated in the drafting of the Medicare and Medicaid statutes, and the new "clear notice" standard could lead to far-reaching effects on these forty-year-old programs. Arlington presents a shift in the Court's Spending Clause jurisprudence that, despite some uncertainties regarding the scope of the ruling, is likely to affect federal healthcare schemes by requiring Congress to provide clearer notice to the states of conditions of accepting federal funds. This Article concludes that the stricter standard of Arlington indicates that the Clawback Provision is unconstitutional, and the provision's fate may portend difficulties for a number of federal healthcare programs. The Court has been drifting toward a narrower view of Spending Clause jurisprudence, and the Roberts Court seems likely to continue to push toward that narrowed interpretation.

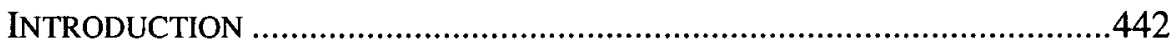

I. WHERE SPENDING ClAUSE JURISPRUDENCE HAS BEEN ................446

A. Pennhurst and Progeny......................................................447

1. Pennhurst and Unambiguous Conditions .........................447

2. South Dakota v. Dole and Spending Limitations................450

3. Subsequent Spending Clause Decisions .........................452

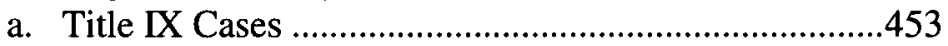

b. The Healthcare/Medicaid Series ...................................457

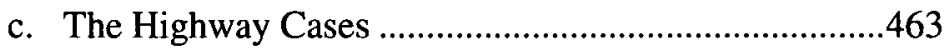

B. Arlington-A Spending Clause Benchmark.............................465

1. Context for Arlington ......................................................466

2. Reaching Beyond the Circuits-Arlington at the Supreme Court.

II. IMPACT OF SPENDING CLAUSE JURISPRUDENTIAL MODIFICATIONS

A. Constitutional Foundations for Federal Healthcare

Programs

B. The Medicare Clawback Provision

C. The States' Challenge to the Clawback Provision ....................483

D. Analysis of the Clawback in Light of Arlington.......................486 CONCLUSION

\section{INTRODUCTION}

The Spending Clause gives Congress a vast amount of power that, at least for the past two decades or so, has been virtually unlimited.' And yet, 
the Spending Clause has spawned a relatively small body of case law considering the expansive nature of the power. ${ }^{2}$ In the 2005-06 Supreme Court Term, the newly minted Roberts Court heard a case that seemed to require simple statutory interpretation. The Court chose, however, to use the case to articulate a new, narrower standard with which to review federal conditions placed on state acceptance of federal funds. Not many have taken note of the case, Arlington Central School District Board of Education v. Murphy, ${ }^{3}$ but Arlington may become a benchmark in Spending Clause jurisprudence for redefining the kind of notice states must have in order to knowingly accept conditioned federal spending.

The architects of existing Spending Clause jurisprudence are no longer on the bench, and the new appointments to the Supreme Court have aligned with the Justices who would have altered the course of Spending Clause jurisprudence during the Rehnquist years. Then-Justice Rehnquist was the author of both Pennhurst State School \& Hospital v. Halderman ${ }^{4}$ and South Dakota $v$. Dole, ${ }^{5}$ two cases that created the modern structure of Spending Clause analysis. The late Chief Justice Rehnquist was a mainstay of the

..." U.S. CONST. art. I, $\S 8, \mathrm{cl} .1$. The "power to spend" (unlike the power to tax) is not explicitly stated in the Constitution, though it is presumed from the language "Provide for the ... general Welfare." See id. Blackletter law states that Congress was given power in the Constitution that enables it to tax and to spend the revenue from taxation for the general welfare. See John E. NowaK \& Ronald D. Rotunda, PRINCIPLES OF CONSTITUTIONAL LAW 112 (2d ed. 2004). The spending power is viewed traditionally as a separate enumerated power for Congress that enables the federal government to spend for the general welfare and to place conditions on the use of federal funds, even if exercise of the spending power would not be supported by another enumerated power. See 1 LAURENCE H. TRIBE, AMERICAN CONSTITUTIONAL LAW 834-41 (3d ed. 2000); Lynn A. Baker \& Mitchell N. Berman, Getting Off the Dole: Why the Court Should Abandon Its Spending Doctrine, and How a Too-Clever Congress Could Provoke It to Do So, 78 IND. L.J. 459, 460 (2003) (arguing the Spending Clause power is virtually unlimited because governed by the "extremely generous" opinion in South Dakota v. Dole, 483 U.S. 203 (1987)); see also Lynn A. Baker, Conditional Federal Spending After Lopez, 95 Colum. L. REv. 1911 , 1914 (1995) (noting how the breadth of the Spending Clause power defeats limits on the Commerce Clause). Some have suggested that the power to spend lies elsewhere; for instance, Professor Engdahl asserts that the power is better founded in Article IV, the "property clause." See generally David E. Engdahl, The Basis of the Spending Power, 18 SEATTLE U. L. REV. 215 (1995) (theorizing that the general welfare phrasing in Article I, Section 8 is merely introductory and does not qualify as an enumerated power and that the Property Clause provides a stronger foundation for Congress's power to spend). The power to spend was aggrandized by the Sixteenth Amendment, which gave the federal government the power to tax personal income and significantly increased the funds available to Congress for spending. See U.S. CONST. amend. XVI.

2. See TRIBE, supra note 1, at 833 (predicting that the power to spend would become even more expansive after United States v. Lopez, 514 U.S. 549 (1995), which limited Congress's Commerce Clause power for the first time in almost sixty years).

3. 548 U.S.

4. 451 U.S. $1(1981)$.

5. 483 U.S. 203 (1987). 
benchmark cases, and his absence facilitates their modification. ${ }^{6}$ Additionally, Justice O'Connor's opinions in key Spending Clause cases created majorities that would not have existed but for her viewpoint. ${ }^{7}$ The new Justices' votes in Arlington signal a willingness to revisit Spending Clause jurisprudence; the surprise of Arlington was how quickly the Court reached this constitutional issue.

More specifically, under the Pennhurst and Dole regime, the Court required Congress to provide "unambiguous" or "adequate" conditions on spending, which seemed to be sufficient for the clear statement rule the Court was seeking to institute. ${ }^{8}$ In Arlington, the Court revised the foundational clear statement rule from requiring "unambiguous conditions" on spending to a "clear notice" standard that appears to demand more specific statutory language from Congress and that is particularly attuned to the state's viewpoint. ${ }^{9}$ This analytical shift may narrow Congress's ability to place conditions on federal spending, yet it fails to acknowledge the overlap between unambiguous conditions and federal coercion of states, as this Article will explore in the context of federal healthcare programs.

The federal government currently accounts for approximately forty percent of healthcare spending each year, a direct result of Congress's power to spend for the general welfare. ${ }^{10}$ The effects of fluctuations in spending jurisprudence would be felt acutely in Medicare and Medicaid,

6. See Baker \& Berman, supra note 1, at 485-86 (noting that so long as Chief Justice Rehnquist remained on the Supreme Court, "pride of authorship" would likely prevent any change in the Dole analysis of conditions placed on federal spending).

7. See infra Part I.A.3.

8. See generally Thomas M. Merrill, Rescuing Federalism After Raich: The Case for Clear Statement Rules, 9 LEWIS \& CLARK L. REV. 823 (2005). Seeking consistencies in the Rehnquist Court's mission to judicially enforce principles of federalism, Professor Merrill explains that two phases existed, the first being the creation of "clear statement rules in federalism controversies" and the second being a period of creating "prohibitory limitations." Id. at 825-26. Professor Merrill describes the key features of clear statement rules as containing an identification of an area that threatens to exceed legislative power; a signal of certain language when the legislature determines to enter that zone; and an opportunity for the Court to review the legislative "signal" and any other legislative findings to determine if the clear statement rules have been satisfied. Id. at $827-28$. He also notes that, though they are preferable in certain areas, clear statement rules can be problematic if the Court changes the standard of what it expects in a clear statement and what qualifies as a clear statement. Id. at 832. In Arlington, the Court may be returning to clear statement rather than prohibitive rules, but it has shifted the foundation of conditional spending in doing so.

9. Arlington Cent. Sch. Dist. Bd. of Educ. v. Murphy, 548 U.S. , 126 S. Ct. 2455 , 2459 (2006).

10. See The Henry J. Kaiser family foundation, Trends and Indicators in the Changing HealthCARE MARKETPLACE $\S 1$ exhibit 1.8 (2006), available at http://www.kff.org/insurance/ 7031 print-secl.cfm (reporting that the various federal programs, including Medicare $(19.2 \%)$ and Medicaid (17.4\%), accounted for $44.4 \%$ of healthcare expenditures in 2004). 
which are "mandatory" spending programs (meaning that Congress has decided, as a matter of legislative mandate, that federal dollars must be spent on these programs). " Changes in spending power doctrine will affect both federal healthcare programs and those who rely on them, including states participating in federal healthcare programs, healthcare providers, and patients. To focus the potentially grand sweep of this observation, this Article will analyze a provision in the Medicare Prescription Drug, Improvement, and Modernization Act of 2003 (the "MMA") known as the "Clawback Provision" that has a direct effect on states and an indirect effect on impoverished Medicare beneficiaries ("dual eligibles"). The Clawback Provision provides a timely example of the effects of changes in Spending Clause jurisprudence after Arlington, as it has been challenged by Kentucky, New Jersey, Texas, Maine, and Missouri (the "Petitioners"). ${ }^{12}$ Though states historically have covered drug expenses for dual eligibles through Medicaid, as a result of the new Medicare drug benefit, the Clawback Provision shifts responsibility for dual eligibles' drugs to Medicare while requiring states to pay the federal government the cost of pharmaceuticals for the foreseeable future. ${ }^{13}$ The Supreme Court has denied original jurisdiction, but the Petitioners have continued their fight at the administrative level, and the Attorneys General for the aforementioned States are contemplating moving forward in district courts as well. ${ }^{14}$

This Article will analyze the progression of Spending Clause jurisprudence and advance the idea that the "unambiguous conditions" test, which was interpreted to mean "adequate notice" by Justice O' Connor and

11. This is differentiated from "discretionary spending," which Congress may or may not choose to effectuate in any given year. See CONG. BUDGET OFFICE, THE BUDGET AND ECONOMIC OUTLOOK: FISCAL YEARS 2006 TO 2015, at 54 box 3-1 (2005), available at http://www.cbo.gov/ftpdocs/60xx/doc6060/01-25-BudgetOutlook.pdf. In this document, the Congressional Budget Office ("CBO") describes the classifications of federal spending as "mandatory," "discretionary," and "net interest" spending. Id.

12. See Texas v. Leavitt, 548 U.S. 126 S. Ct. 2915, 2915 (2006) (mem.) (denying original jurisdiction). Ten states filed an amicus brief (Alaska, Arizona, Connecticut, Kansas, Mississippi, New Hampshire, Ohio, Oklahoma, South Carolina, and Vermont) and a coalition of health law professors also filed an amicus brief. See generally Brief of Professors and Practitioners of Health Law as Amici Curae in Support of Plaintiffs, Leavitt, 548 U.S. _, $126 \mathrm{~S}$. Ct. 2915 (2006) (mem.) (No. 05-135). In the interest of full disclosure, this author signed the amicus brief.

13. See Medicare Prescription Drug, Improvement, and Modernization Act of 2003, Pub. L. No. 108-173, § 103(b),117 Stat. 2066, 2155-58 (2003). Medicare Part D is codified at 42 U.S.C.A. $\$ \S 1395 w-101$ to -152 (West 2003 \& Supp. 2007). The Clawback Provision is codified at 42 U.S.C.A. $§ 1396 u-5$ (West 2003 \& Supp. 2007). For additional discussion of dual eligibles, see infra Part II.B.

14. See States Request CMS Action on Clawback, Part D Stopgap, 9 INSIDE CMS 1, 9 (2006) (on file with the North Carolina Law Review) (describing the states' efforts to have the Center for Medicare and Medicaid Services administratively change the fiscal impact of the Clawback). 
which guided the Court's majorities for two decades, evolved into the "clear notice rule" that emerged in Arlington. It can be helpful to consider modern Spending Clause cases in terms of subject matter to demonstrate the trends in Spending Clause doctrine. ${ }^{15}$ The Title IX series of cases penned by Justice O'Connor and the cases related to healthcare shed light on the alignments in the Rehnquist Court and the trends that may soon be observed in the Roberts Court. The Title IX cases also reveal, through Justice Kennedy's dissents regarding the "adequate notice" standard, that Arlington should not have been unforeseen. The healthcare cases demonstrate the Supreme Court's reluctance to touch Medicare and Medicaid, the inability of the lower courts to apply Spending Clause doctrine in a meaningful way to the federal healthcare programs, and the import of changes in Spending Clause jurisprudence for healthcare programs in general.

After evaluating the trends in the Spending Clause power with regard to federal healthcare issues, this Article will study the Clawback Provision. Considering the Petitioners' case in light of Arlington helps illustrate the effect of the new Spending Clause articulation on federal healthcare legislation. Significantly, because of the Clawback Provision, states must fund the Medicare drug benefit for dual eligibles or face a total loss of Medicaid funds, which prevents states from choosing whether to provide a drug benefit to these Medicaid beneficiaries.

Arlington seems to require clarity of language that could not have been anticipated in the drafting of the Medicare and Medicaid statutes, and the new "clear notice" standard could lead to far-reaching effects on these forty-year-old programs. Arlington presents a shift in the Court's Spending Clause jurisprudence that, despite some uncertainties regarding the scope of the ruling, is likely to affect long-standing federal healthcare schemes by requiring the federal government to provide to the states clearer notice of conditions of accepting federal funds. This Article concludes that the stricter standard of Arlington indicates that the Clawback Provision is unconstitutional, and the provision's fate may foretell difficulties for a number of federal healthcare statutes (if not programs). The Court has been drifting toward a narrower view of Spending Clause jurisprudence, and the Roberts Court seems likely to continue to push toward that narrowed interpretation.

\section{Where SPENDing Clause JuRISPRUDENCE HAS BEeN}

Pennhurst has emerged as the true foundation for current Spending Clause analysis. This section will review the progression of Spending

15. Subject matter characterization can be the key to any analysis. See infra note 49 . 
Clause cases after Pennhurst and will examine a particular string of dissents that signaled the desire (by those who are now part of the Court's majority) to require more stringent application of the Pennhurst unambiguous conditions language. From this line of cases, the section will explore the implications of Spending Clause jurisprudence in healthcare cases and provide examples of the consistency of the divide between the Rehnquist Spending Clause majority and what has become the Roberts majority.

\section{A. Pennhurst and Progeny}

Pennhurst concerned the requirements of the Developmentally Disabled Assistance and Bill of Rights Act (the "Act"), in particular $\$ 6010$ of the Act (the so-called Bill of Rights section).$^{16}$ Plaintiffs, residents at an institution for the mentally retarded, contended that the Bill of Rights in $\S 6010$ protected them from the restrictive and abusive treatment that they received in the Pennhurst facility. ${ }^{17}$ The Third Circuit, affirming the lower court's decision, agreed and held that $\S 6010$ guaranteed “ 'appropriate treatment, services, and habilitation' in 'the setting that is least restrictive of ... personal liberty' " and that residents of Pennhurst's facility could enforce these rights through civil actions, even though no cause of action was specified in the statute. ${ }^{18}$

\section{Pennhurst and Unambiguous Conditions}

Then-Justice Rehnquist's 1981 opinion held that legislative findings and declarations cannot impose specific, enforceable standards on states simply because they accept federal funding. ${ }^{19}$ The federal government may provide funds to the states to encourage certain behavior, and conditions may be placed on those federal funds so long as states are free to reject the funds and their attendant conditions. ${ }^{20}$ The Pennhurst majority noted that Congress specified the conditions for the use of federal funds clearly in the

16. Pennhurst State Sch. \& Hosp. v. Halderman, 451 U.S. 1, 8 (1981) (citing 42 U.S.C. $\S \S 6010(1)$, (2) (1976 \& Supp. III 1979)).

17. Id. at 6 . The district court found that the conditions at Pennhurst were so abysmal that some patients regressed during their stay, and many of the residents were abused, drugged, or left alone to the point of danger. Id. at 7 (citing Halderman v. Pennhurst State Sch. \& Hosp., 446 F. Supp. 1295, 1308-10 (E.D. Pa. 1977)).

18. Id. at 8-9. The dissent at the circuit court emphasized that general statutory findings and declarations did not and could not impose a specific " 'least restrictive treatment" " standard on the states and concluded that $\S 6010$ created no substantive rights enforceable by Pennhurst's residents. Id. at 10 (citing Halderman v. Pennhurst State Sch. \& Hosp., 612 F.2d 84, 119 (1979) (en banc) (Seitz III, J., dissenting)).

19. Id. at 18 .

20. Id. at 11 . 
Act by conditioning the use of federal money on performance of certain obligations, such as affirmative action in hiring, care plans for residents of facilities, and systems to protect the rights of the developmentally disabled. On the other hand, as read by the Court, $\S 6010$ was not a condition of funding given the language of the statute itself. ${ }^{21}$

In analyzing the ability of Congress to place conditions on the use of federal funds, the Court emphasized a now-familiar analogy that Spending Clause legislation is "in the nature of a contract." 22 Thus, for a state to be able to enter into a "contract" with the federal government, it must know what is expected of it, which means that conditions imposed by the federal government must be voluntarily accepted. According to Justice Rehnquist's analysis, voluntary acceptance can occur only if the conditions are "unambiguous." 23 The majority wrote: "By insisting that Congress speak with a clear voice, we enable the States to exercise their choice knowingly, cognizant of the consequences of their participation." ${ }^{24}$ Section 6010 could not be read to create a requirement to fund certain rights for mentally retarded citizens because the condition was not stated specifically in the statute or its legislative history and because the Court was reluctant to read a "high cost" requirement into the Act. ${ }^{25}$ Instead, the majority read the $\S 6010$ Bill of Rights as a hortatory statement by Congress encouraging states to find methods to properly care for their mentally retarded citizens. ${ }^{26}$ In short, the Pennhurst majority determined that the Act could not have

21. Id. at 12-13. In explaining why the Court was reluctant to infer an affirmative obligation to provide a "least restrictive environment" under Section 5 of the Fourteenth Amendment, Justice Rehnquist noted that the "case for inferring intent is at its weakest where, as here, the rights asserted impose affirmative obligations on the States to fund certain services, since we may assume that Congress will not implicitly attempt to impose massive financial obligations on the States." Id. at 16-17. The majority thus turned to a Spending Clause analysis rather than an analysis under the Fourteenth Amendment. Id. at 17.

22. Id.

23. The key language states:

[L]egislation enacted pursuant to the spending power is much in the nature of a contract: in return for federal funds, the States agree to comply with federally imposed conditions. The legitimacy of Congress' power to legislate under the spending power thus rests on whether the State voluntarily and knowingly accepts the terms of the "contract." There can, of course, be no knowing acceptance if a State is unaware of the conditions or is unable to ascertain what is expected of it. Accordingly, if Congress intends to impose a condition on the grant of federal moneys, it must do so unambiguously.

Id. (emphasis added) (citations omitted).

24. Id.

25. Id. at 18 .

26. Id. at 19-20. Justice Rehnquist wrote: "Much like the Medicaid statute considered in Harris v. McRae, ... the Act at issue here was designed as a cooperative program of shared responsibilit[ies], not as a device for the Federal Government to compel a State to provide services that Congress itself is unwilling to fund." Id. at 22. 
intended to impose an affirmative obligation on the states because the funding for creating "least restrictive" environments for the mentally retarded citizens of each state was nonexistent. ${ }^{27}$ The Court refused to infer "massive" financial obligations for the states from unstated conditions on acceptance of federal funding. ${ }^{28}$

A number of reasons exist for lingering over Pennhurst. First, it has become the principal source of authority for Justices who have advanced the "clear notice" requirement for conditions on spending, as will be discussed below. The language within Pennhurst first created a requirement for "unambiguous conditions," but, in a summary description by the Court of its holding in the case, was restated later in the opinion as a requirement that Congress must provide "clear notice to the States that they, by accepting funds under the Act, would indeed be obligated to comply with $\S 6010$." 29 This reiteration included dicta that states could not reasonably be expected to comply with " "retroactive' conditions." 30 But the "clear notice" language was not delivered by the Pennhurst Court as a constitutional test; it was part of a summary of the Court's holding. ${ }^{31}$ Second, the idea of clear notice is sound if it means that funding recipients must have notice of potential liabilities before they can properly enter into an agreement with the government to accept funds and the conditions that accompany them. The clear notice requirement may not actually achieve the "contract like" agreement that the Court seeks, particularly in the context of long-standing federal programs. Third, the clear notice requirement may not be doctrinally satisfying if the Court is seeking to institute a clear statement rule that provides guidance to both Congress and the states. Thus, the evolution of the clear notice requirement is important to trace, as it appears to be the newly focused lens through which the Spending Clause is to be interpreted.

27. Id. at 24 .

28. Id.

29. Id. at 25 .

30. Id. This sentiment has not carried over into cases involving challenges to Medicaid conditions on spending, even though states started participating in Medicaid decades ago and nearly every new condition is retroactive.

31. Id. As will be discussed later, Justice Ginsburg appeared reluctant to adopt the clear notice requirement in Arlington Central School District Board of Education v. Murphy, 548 U.S. 126 S. Ct. 2455, 2464 (2006) (Ginsburg, J., concurring), for reasons mentioned here and because the nature of the condition in Pennhurst is distinguishable from the nature of the condition in Arlington. 


\section{South Dakota v. Dole and Spending Limitations}

Six years after Pennhurst, Chief Justice Rehnquist also penned South Dakota v. Dole. ${ }^{32}$ As Professor Baker has noted in explaining the history of Dole through the handwritten notes of Justice Blackmun, the Justices appear to have perceived the case as a simple, unimportant decision. ${ }^{33}$ Dole involved federal highway funding that contained a condition that states mandate a minimum drinking age of twenty-one or face the loss of five percent of federal highway funds. ${ }^{34}$ The nature of the condition was not at issue; the states understood the condition clearly, but they believed that the Twenty-first Amendment ${ }^{35}$ trumped the federal government's power to indirectly regulate the drinking age. ${ }^{36}$

Chief Justice Rehnquist began with the principle that Congress can spend for the general welfare and can attach conditions to spending to influence behavior and to further policy objectives. ${ }^{37}$ The Court also confirmed the doctrinal origin of the Spending Clause, United States $v$. Butler, ${ }^{38}$ which espoused the expansive "Hamiltonian" view of the power to spend as a separate enumerated power. ${ }^{39}$ Despite the broad foundation of the spending power, the Court enumerated instances in which the power might be limited. To that end, the Court set forth a test, which stated that (1) the power to spend must be used in pursuit of the general welfare, a determination in which the Court defers to Congress; (2) when conditions are imposed on the use of federal funds, they must be "unambiguous" so that states understand the "consequences" of accepting federal funds, ${ }^{40}(3)$ conditions may be imposed only if they are related to the federal interest in spending federal funds, otherwise known as the "germaneness" requirement; and (4) conditions placed on funds may not violate other

32. 483 U.S. 203 (1987).

33. Lynn A. Baker, Federalism and the Spending Power from Dole to Birmingham Board of Education, in THE REHNQUIST LEGACY 205, 208 (Craig Bradley ed., 2006) (stating that the test set forth in Dole appears to be "casually" created and that the case was not "an especially important one").

34. Dole, 483 U.S. at $205-06$.

35. U.S. CONST. amend. XXI, $\$ 2$ ("The transportation or importation into any State, Territory, or possession of the United States for delivery or use therein of intoxicating liquors, in violation of the laws thereof, is hereby prohibited.").

36. Dole, 483 U.S. at 205-06.

37. Id. at 206-07 (citing Steward Mach. Co. v. Davis, 301 U.S. 548 (1937) (upholding social security and thus allowing one of the now-oldest and largest federal spending programs to exist; it was part of the model for and statutory basis of Medicare and Medicaid in the 1960s)).

38. 297 U.S. 1, 65-66 (1936) (adopting Justice Story's analysis and approval of Hamilton's expansive view of the spending power).

39. Dole, 483 U.S. at 207.

40. Pennhurst thereby became one of the limiting elements of Spending Clause analysis. Dole, 483 U.S. at 207 (citing Pennhurst State Sch. \& Hosp. v. Halderman, 451 U.S. 1, 17 (1981)). 
provisions of the Constitution, otherwise known as the prohibition on unconstitutional conditions. ${ }^{41}$ An unenumerated fifth category in Dole comes in the form of dicta that at some point the money offered by Congress may be "so coercive as to pass the point at which 'pressure turns into compulsion." ",42 In Dole, however, such a turning point was not reached, as a loss of five percent of funds was considered to merely be "mild encouragement."

Justice O'Connor's dissent is important because, even though she disagreed with the Court's application of the germaneness element, she agreed with the Court's articulation of limits on spending and the elements of the Dole test. ${ }^{44}$ Her vote became the essential fifth in many cases after Dole, and her interpretation of unambiguous conditions (which she called "adequate notice") dominated until she retired from the Court. ${ }^{45}$ Justice O'Connor's dissent stated that the law failed not only regarding the relatedness of the condition to the spending, but also by intruding into

41. Id. at 207-08. The majority then undermined its own analysis of limitations on the spending power by noting that the determination as to whether spending is for the general welfare is a political question and potentially nonjusticiable. $I d$. at $207 \mathrm{n} .2$. Amicus briefs urged the Court to adopt a stronger germaneness test; they sought a requirement that conditions be directly related to the purpose for which funds are spent. The majority rejected the "direct relation" requirement and instituted a "reasonably related" requirement. $1 d$. at 209 n.3.

42. Id. at 211 (quoting Steward Mach. Co. v. Davis, 301 U.S. 548,590 (1937)).

43. Id. at 211.

44. Justice O'Connor scrutinized the federal government's desire to deter highway accidents through preventing teenage drunk driving and found the analysis lacking in all regards; the condition was underinclusive because teenagers are a small percentage of drunken driving accidents and yet the condition was overinclusive because teenagers are not permitted to drink even when they have no intent to drive. See id. at 214-15 (O'Connor, J., dissenting).

45. See Jackson v. Birmingham Bd. of Educ., 544 U.S. 167, 181 (2005) (O'Connor penned the majority and adhered to adequate notice theory set forth in Davis); Sabri v. United States, 541 U.S. 600, 608 (2004) (O'Connor with the majority rejecting the defendant's coercion theory in challenging a statute that rendered local bribery a federal crime); Pierce County v. Guillen, 537 U.S. 129,148 n.9 (2003) (unanimous decision that deliberately ignored the Spending Clause aspect of the Washington State Supreme Court's analysis and instead relied on Commerce Clause analysis); Barnes v. Gorman, 536 U.S. 181, 186-87, 190-91 (2002) (Scalia, writing for the majority, relied heavily on the contract analogy from Pennhurst, calling acceptance of conditions a contract, while Souter's concurrence, which O'Connor joined, rejected use of Pennhurst standards and the contract analogy); Davis v. Monroe County Bd. of Educ., 526 U.S. 629, 641-46 (1999) (O'Connor authored the majority that held adequate notice regarding funding conditions need not be found in language of the statute); Franklin v. Gwinnett County Pub. Sch., 503 U.S. 60, 74-75 (1992) (O'Connor in the majority, holding that intentional violations of Title IX were not subject to the unambiguous conditions requirement); Bennett v. Ky. Dep't of Educ., 470 U.S. 656, 665-69 (1985) (O'Connor authored the majority opinion and limited the contract theory from Pennhurst). In Arlington, Justice Alito has given majority imprimatur to the clear notice requirement, which was the favored language of the dissenters in the above-noted cases. Arlington Cent. Sch. Bd. of Educ. v. Murphy, 548 U.S. 126 S. Ct. 2455, 2459 (2006). 
traditional areas of state control, namely the state's "social and economic life," thus foreshadowing her opinion in New York $v$. United States. ${ }^{46}$

Courts have failed to enforce at least two parts of the Dole test-the requirement to spend for general welfare and the relatedness element. ${ }^{47}$ Critics of Dole have appraised the germaneness requirement and the coercion element as not only unworkable for lower courts but also strangely overlooked, despite Justice O'Connor's dissent. ${ }^{48}$ And the unambiguous conditions element, now known as the clear notice requirement, has been largely ignored as a limit on congressional power.

\section{Subsequent Spending Clause Decisions}

Post-Dole cases can be divided into two groups: the Title IX cases penned by Justice O'Connor and the healthcare cases primarily decided in the lower federal courts. ${ }^{49}$ These decisions shed light on the alignments in

46. Dole, 483 U.S. 203, 215 (O'Connor, J., dissenting). This is interesting for at least two reasons. First, the majority in Dole explicitly accepted the theory of Oklahoma v. Civil Service Commission, 330 U.S. 127 (1947), that the Tenth Amendment does not limit the conditions Congress can place on federal funds because states can reject the federal funds and thereby avoid coercion. Id. at 210 (majority opinion). Second, Justice O'Connor subsequently authored the majority opinion in New York v. United States, in which the Court again rejected the Tenth Amendment as a limitation on the Spending Clause power (though it was interpreted as a judicially enforceable limit on the Commerce Clause power). New York v. United States, 505 U.S. 144, 173 (1992). Thus, with the authors of Dole and New York no longer on the Court, doctrinal changes could occur in more than one respect for the spending power. Some scholars have argued that the Tenth Amendment should be read as a limit on the spending power because states no longer have the political power or money to reject offers of federal funds. See Brian Galle, Getting Spending: How To Replace Clear Statement Rules with Clear Thinking About Conditional Grants of Federal Funds, 37 CONN. L. REv. 155, 184-85 (2004) (stating that the Tenth Amendment should act as a limit on the spending power as it does for the Commerce Clause power); Thomas R. McCoy \& Barry Friedman, Conditional Spending: Federalism's Trojan Horse, 1988 SUP. CT. REV. 85, 116-20, 123-27 (describing Rehnquist's reliance on the political process and decrying the lack of seriousness regarding the idea of coercing states). For a pre-Dole analysis, see generally Albert J. Rosenthal, Conditional Federal Spending and the Constitution, 39 STAN. L. REV. 1103 (1987).

47. See, e.g., Baker \& Berman, supra note 1, at 464-65 (describing that only three of the five Dole elements have been enforced by courts).

48. Dole, 483 U.S. at 212-18. Justice O'Connor did not disagree with the majority's analysis of the Spending Clause power or the test created by the majority. Instead, she disputed the Court's factual analysis of the germaneness requirement. While not disputing that conditions may be placed on federal funds, Justice O'Connor stated that "establishment of a minimum drinking age of 21 is not sufficiently related to interstate highway construction to justify so conditioning funds appropriated for that purpose." $I d$. at 213-14.

49. Subject matter itself can be perceived differently by different people, even on the Supreme Court. For example, in developing a theory of modern federalism, Professor Baker describes Justice O'Connor as seeing Davis v. Monroe County Board of Education, 526 U.S. 629 (1999), as a case about sexual harassment, while the other Justices in the "States' Rights Five" see the case as one about regulation of public schools. See Lynn A. Baker, Lochner's Legacy for Modern Federalism: Pierce County v. Guillen as a Case Study, 85 B.U. L. REv. 727, 760-61 (2005). The subject matter characterization is important because Justice O'Connor's sexual 
the Rehnquist Court and what may come to be observed in the Roberts court. The Title IX cases also reveal, through dissents, deliberate movement toward Arlington's "clear notice" requirement, especially Justice Kennedy's dissent in Davis v. Monroe Board of Education ${ }^{50}$ and Justice Thomas's endorsement of Kennedy's view in Jackson $v$. Birmingham Board of Education. ${ }^{51}$ Circuit courts' handling of healthcare cases reveals the inability of the lower courts to apply Spending Clause doctrine to the federal healthcare programs in a meaningful way and the import of changes in Spending Clause jurisprudence for healthcare in general. Finally, the highway cases illuminate the trends in the Title IX and healthcare cases, particularly the significance of the Court's characterization of the conditions on federal spending. ${ }^{52}$

\section{a. Title IX Cases}

Justice O'Connor's retirement and replacement by Justice Alito facilitated the movement from unambiguous conditions on spending, as seen in Dole, to clear notice. Franklin v. Gwinnett County Public Schools $s^{53}$ provides the first insight into Justice O'Connor's prevailing view of unambiguous conditions, or, as she also described it, "adequate notice" when conditions are placed on spending and extra expenses arise as a result of those conditions. Franklin was the first of several cases during the O'Connor years to test plaintiffs' ability to enforce Title IX by seeking damages against a school district for various discriminatory behaviors. ${ }^{54}$ Justice O'Connor joined in the majority opinion authored by Justice White, which held in part that Pennhurst does not require a statute to contain notice of monetary damages when violation of the statute is intentional,

harassment characterization leads her to believe the case is about civil rights (traditionally a matter of federal control) while the regulation of public schools characterization by the dissent leads to an area of traditional state control (education). See id.

50. 526 U.S. 629 (1999).

51. 544 U.S. 167 (2005).

52. See generally Pierce County v. Guillen, 537 U.S. 129 (2003); see also Baker, supra note 49, at 733-34 (discussing how the characterization of conditions on federal spending influences the Court's review of the conditions).

53. 503 U.S. 60 (1992). The student in Franklin alleged that she had been sexually harassed by a teacher and that the school had ignored her complaints; she claimed that Title IX provided a means of recovering damages against the school district for intentionally ignoring the sexual discrimination. See id. at 63-64.

54. Title IX is codified at 20 U.S.C. $\$ 1681(2000)$. In pertinent part, it provides: "[n]o person in the United States shall, on the basis of sex, be excluded from participation in, be denied the benefits of, or be subjected to discrimination under any education program or activity receiving Federal financial assistance." $§ 1681(a)$. Congress created a spending scheme wherein schools that accept federal funds must ensure, as a condition of accepting the funds, that female students are not subject to gender discrimination. Though no private cause of action is delineated in the statute, one was found in Cannon v. University of Chicago, 441 U.S. 677, 688-89 (1979). 
even if the statute is enacted under the Spending Clause and conditions are imposed on receipt of funds as part of the statutory scheme. ${ }^{55}$ Though Justice Kennedy sided with the majority in Franklin, the next Title IX remedies decision provided an important Kennedy dissent.

In Davis v. Monroe Board of Education ${ }^{56}$ a pattern emerged. In this case of Title IX discrimination, the Court held that damages could be imposed on a school district for intentionally ignoring "student-on-student" sexual harassment. ${ }^{57}$ Justice O'Connor's majority opinion built on Franklin: intentional behavior by the school district could be deemed a violation of Title IX that is enforceable by private action, even though the cause of action is implied from, not stated in, the language of the federal statute. $^{58}$ Justice O'Connor articulated that Title IX, as a Spending Clause statute, was limited in its scope by the requirement that states have "adequate notice" of the terms of spending. ${ }^{59}$ Justice O'Connor's interpretation of Pennhurst's notice requirement is key: the state was only required to have "adequate" notice of federal conditions in order for the conditions on spending to be constitutional (and that adequate notice need not be explicit within the statute at issue in order to be valid). This reading of Pennhurst created the main point of contention for the dissent.

The Davis dissent authored by Justice Kennedy has become the majority view in the Roberts Court. Justice Kennedy began by noting that, read broadly, Dole would permit the federal government to regulate in ways that Article I would not otherwise allow through the use of conditions

55. Franklin, 503 U.S. at 74-75. The Court did not cite Dole in this analysis; its focus was Pennhurst and the meaning of limiting remedies in a Spending Clause statute. See id. This aspect of the holding inspired a rebuttal in the concurrence penned by Justice Scalia (joined by Chief Justice Rehnquist) that presages Arlington by showing that implied remedies were considered suspect by the "states' rights" Justices. See id. at 77-78 (Scalia, J, concurring in the judgment). The voting block of Chief Justice Rehnquist, Justice O'Connor, Justice Scalia, Justice Kennedy, and Justice Thomas has been described as the "states' rights five," but in Spending Clause cases they are the "states' rights four" because Justice O'Connor voted with the "individual rights four." See, e.g., Lynn A. Baker, The Future of Federalism? Pierce County v. Guillen as a Case Study, 50 N.Y.L. SCH. L. REV. 699, 700 n.4 (2006) (listing the above-named justices as the crucial five beginning with New York v. United States (citing Editorial, Fiddling with Federalism, N.Y. TIMES, Oct. 15, 1999, at A34 (referring to these Justices as the "states' rights five"))); see also Linda Greenhouse, Court's Term a Turn Back to the Center, N.Y. TIMES, July 4, 2005, at A1 (noting that Justices Scalia, Thomas, Kennedy, O'Connor, and Chief Justice Rehnquist were the most conservative justices and tended to vote in a bloc).

56. 526 U.S. 629 (1999).

57. Id. at 653-54. Ultimately, the Court held that the school district had a duty to protect the student because it accepted conditioned federal funds and that deliberately ignoring the harassed student's plea for protection could constitute intentional conduct that violated Title IX's proscriptions. Id. at 642-44 (discussing the development of the "deliberate indifference" theory of liability under Title IX).

58. Id. at 639-40.

59. Id. at 640 . 
on grants of federal money. According to the dissent, this "has the potential to obliterate distinctions between national and local spheres of interest and power by permitting the Federal Government to set policy in ... areas of traditional state concern ...."60 To rein in the Spending Clause power, the dissent emphasized the importance of Pennhurst's standard and of the nature of the contract between the state and the federal government, asserting such measures are "concrete safeguard[s] in the federal system." 11 Justice Kennedy continued: "Only if States receive clear notice of the conditions attached to federal funds can they guard against excessive federal intrusion into state affairs and be vigilant in policing the boundaries of federal power." 62

This seems to be the first articulation of the effort to interpret Pennhurst as establishing a "clear notice" requirement, rather than the "adequate notice" standard supported by the majority in Davis. ${ }^{63}$ The dissent explained its fundamental difference of opinion, that the Title IX provision contained no private cause of action, and therefore it could not be read to meet the standard of Pennhurst. ${ }^{64}$ The dissent also noted a temporal concern: that the state receive clear notice of the condition at the time the state accepts the federal funds. ${ }^{65}$ The dissent then ended with a strong endorsement of federalism as a limitation on the federal government, stating that the majority failed to recognize that key element of the case. ${ }^{66}$

A third decision in the Title IX series, Jackson v. Birmingham Board of Education, ${ }^{67}$ also would have had a different outcome without Justice

60. Id. at 654 (Kennedy, J., dissenting) (citing South Dakota v. Dole, 483 U.S. 203, 207 (1987)).

61. Id. at 655 .

62. Id. (emphasis added).

63. Kennedy stated this difference strongly: "While the majority purports to give effect to these principles, it eviscerates the clear-notice safeguard of our Spending Clause jurisprudence." Id.

64. Id. at 656 . This analysis rebuffs the reasoning of Franklin in addition to rejecting the Davis holding.

65. Id. at 656-57.

66. This point furthers the perception that the dissent believed the case was about education, not sexual discrimination. Some argue that federalism, as a matter of linguistics, does not connote limitation of the power of the federal government to empower the states. See, e.g., CaSs SUNSTEIN, ThE PARTIAL CONSTITUTION 135 (1993) (describing federalism as a neutral founding principle akin to judicial review, national representation, and checks and balances); Erwin Chemerinsky, Protecting the Spending Power, 4 CHAP. L. REv. 89, 99 (2001) (defending the expansive interpretation of the Spending Clause power and noting that the idea of "dual sovereignty" is not normative unto itself and that to be meaningful, federalism should be supported by an underlying theory, but that states' rights judges tend to simply assume a normative connotation).

67. 544 U.S. 167 (2005). In Jackson, a male physical education teacher and coach complained of sex discrimination in the school's athletics program and was fired from his 
O'Connor's voice. Continuing the debate regarding implied causes of action under Title IX, the Court held that the school could be liable for discrimination-related damages for retaliation because it is "an intentional act" and thus within the meaning of sex-based discrimination. ${ }^{68}$ The Court rejected the school's assertion that it was not "on notice" that it could be held liable for retaliation, as intentional acts that violate Title IX have always been prohibited in the Court's interpretation of Title IX. ${ }^{69}$ The majority reiterated the holding from Davis that intentional violation of the statute creates its own "sufficient notice" that removes any bar to Title IX liability, thus affirming a less demanding notice standard, as was seen in Franklin. $^{70}$

Justice Thomas's dissent (joined by Chief Justice Rehnquist and Justices Kennedy and Scalia) attacked the majority's reading of Pennhurst by emphasizing that the conditions attached to spending legislation must be "clear" due to the contractual nature of spending clause statutes. ${ }^{71} \mathrm{He}$ noted that without clear notice of conditions, a state cannot knowingly and voluntarily participate in federal funding programs. ${ }^{72}$ The Jackson dissent adhered to the language of Justice Kennedy's dissent in Davis and reiterated the ideal that federal spending statutes must provide "clear" notice when they impose conditions. ${ }^{73}$

coaching job for repeated complaints of unequal funding and access for his girls' basketball team. Id. at $171-72$.

68. Id. at 173-74. Because the statute aims to prevent discrimination, the majority noted that the line of Title IX cases consistently has held that discrimination should be read broadly. Id. at 174-75. This is consistent with Professor Baker's observation that the majority views sex discrimination in schools as a civil rights issue, and thus would read the federal power to condition spending more broadly. See Baker, supra note 49, at 760-61.

69. See Jackson, 544 U.S. at 182-83.

70. Id. The Court reiterated that retaliation against individuals who complain of sex discrimination is intentional discrimination based on sex that is prohibited by Title IX's "clear terms," and thus no additional notice is required for the state to be liable in a private cause of action. $I d$. at 183.

71. Id. at 190-92 (Thomas, J., dissenting). The dissent also disagreed with the majority's characterization of retaliation as "discrimination on the basis of sex" and departed from the majority because the complaint was based on someone else's sex. Id. at 187 .

72. Id. at 190-91. The dissent also relied on Barnes v. Gorman, 536 U.S. 181 (2002), in which Justice Scalia took the Spending Clause contract analogy to a new level in rejecting a claim for punitive damages under the Americans with Disabilities Act. See Jackson, 544 U.S. at 19091 (citing Barnes v. Gorman, 536 U.S. 181, 186 (2002)). Justices Souter and O'Connor concurred in the decision in Barnes, but they rejected the heavy reliance on contract principles, predicting that they would not be useful in cases seeking, for instance, compensatory damages. See Barnes, 536 U.S. at 190-91 (Souter, J., concurring).

73. Justice Thomas stated that the majority required "clairvoyance" from funding recipients, rather than "clarity from Congress." Jackson, 544 U.S. at 192 (Thomas, J., dissenting). This is a continuation of Justice Kennedy's call for "clear notice" in the statute itself, rather than the Court's interpretation of the statute equating to notice of funding conditions. See Davis $v$. 


\section{b. The Healthcare/Medicaid Series}

In Medicaid-related litigation, states often claim that participation in Medicaid is not voluntary because state medical systems would collapse without Medicaid funding. ${ }^{74}$ This notion of involuntary participation challenges both the clear notice element and the coercion "fifth" element of Dole. Courts have not accepted, however, that states might be unable to stop participating in certain federally funded programs, as will be discussed below. The major cases in the healthcare arena tend to end at the circuit court level, but trends emerge that are worthy of examination both for their descriptive and their predictive qualities. ${ }^{75}$

Harris v. McRae $e^{76}$ is one of the few healthcare cases decided by the Supreme Court, and, though it predated both Pennhurst and Dole, it sheds some light on subsequent Medicaid-related decisions. The case involved a challenge to the Hyde Amendment's limits on abortion funding in Medicaid programs, which prevented federal dollars from being used for any abortion except to save the life of the mother or in cases of rape or incest. ${ }^{77}$ Plaintiffs asserted unconstitutional conditions in challenging the Hyde Amendment (the fourth Dole category), but they also challenged the Amendment on the premise that Medicaid required all participating states to pay for medically necessary surgical services, even if federal funds were unavailable for the treatment. ${ }^{78}$ The Court chose to address the statutory issue regarding the states' obligation to provide Medicaid reimbursement

Monroe Bd. of Educ., 526 U.S. 629, 655 (1999) (Kennedy, J., dissenting). Both result in a call for "clearer" clear statement principles.

74. Medicaid is also known as Title XIX, its section within the Social Security Act. Title XIX is codified at 42 U.S.C. $\S \S 1396,1396 a-v(2000)$. Medicaid is a federally funded healthcare program that helps states serve the population that is poor, plus a qualifying category such as pregnant, disabled, or elderly. $\S 1396 \mathrm{a}(\mathrm{a})(10)$. Though the minimum standards for Medicaid are created in federal statutes and regulations, each state has a different version of Medicaid because some states cover the federally mandated minimum and some states choose to spend more and cover more people and/or items or services through Medicaid. \$1396a; see also CTR. FOR MEdiCAID \& STATE OPERATIONS, U.S. DEP'T OF HEALTH \& HuMAN SERvS., MEDiCaID AT-AGLANCE 2005, at 1-3 (2005), available at http://www.cms.hhs.gov/MedicaidGenInfo/Downloads /MedicaidAtaGlance2005.pdf (describing optional state Medicaid elements).

75. A parallel clearly exists between enforcement of individual rights in the Medicaid program and enforcement of individual rights in the Title IX cases, which this author intends to explore in the near future.

76. 448 U.S. 297 (1980).

77. Id. at 302 .

78. Id. at 304-05. The alternative argument regarding funding shows recognition of the modern Supreme Court's preference for avoiding constitutional questions if possible. Id. at 307 (citing Spector Motor Serv., Inc. v. McLaughlin, 323 U.S. 101, 105 (1944)) (reaffirming that the Court will avoid constitutional questions for jurisprudential, rather than constitutional, reasons if a statutory question can resolve a case). 
for medically necessary services even in the absence of matching federal funds. ${ }^{79}$

The Court first characterized Medicaid as a "cooperative endeavor" by which the federal government gave states the option of providing healthcare to the poor by providing "financial assistance," 80 which the Court summarized as a form of "cooperative federalism." 81 The Court emphasized that Medicaid was a program of "shared financial responsibility, not [] a device for the Federal Government to compel a State to provide services that Congress itself is unwilling to fund." 82 With this foundational interpretation of cooperative federalism, the Court rejected the assertion by the plaintiffs that states would have to subsidize a procedure for which federal funds were unavailable. ${ }^{83}$ The Court refused to believe that states would be responsible for payments that the federal government had deliberately withdrawn. Though the Spending Clause was not discussed specifically in Harris v. McRae, it is the rationale underlying the statutory interpretation given to both the Medicaid program and the Hyde Amendment. ${ }^{84}$

This decision serves as background for West Virginia v. U.S. Department of Health and Human Services, ${ }^{85}$ a Fourth Circuit case involving a Tenth Amendment ${ }^{86}$ challenge to "estate recovery" provisions added to the Medicaid program in $1993 .{ }^{87}$ West Virginia was receiving

79. Harris v. McRae was decided before welfare became a block grant program under Temporary Assistance to Needy Families, the "workfare" law that changed the nature of welfare funding and the old tie-ins between welfare and Medicaid. See Personal Responsibility and Work Opportunity Reconciliation Act of 1996, Pub. L. No. 104-193, 110 Stat. 2105 (1996); see also $\S 1396(\mathrm{~b})(\mathrm{a})(1)(2000)$ (calculations for the federal medical assistance percentage, the new method of paying states to maintain Medicaid programs).

80. Harris, 448 U.S. at 301-02.

81. Id. at 308 .

82. Id. at 309.

83. See id. at 310. The Court clarified that states could choose to fund abortion services, but that they were not required to do so. See id. at $311 \mathrm{n} .16$. Having resolved the statutory issue, the Court determined that the due process right in Roe v. Wade, 410 U.S. 113 (1973), was not infringed by the Hyde Amendment because women had a right to obtain an abortion, but not a right to obtain funding for an abortion. See id, at 315-17 (citing Maher v. Roe, 432 U.S. 464 (1977)).

84. Id. at $310 \mathrm{n} .15$ (noting that state obligations to provide funding for certain medical services were a condition of receiving federal funding).

85. 289 F.3d 281 (4th Cir. 2002).

86. The Tenth Amendment provides: "The powers not delegated to the United States by the Constitution, nor prohibited by it to the States, are reserved to the States respectively, or to the people." U.S. CONST. amend. X.

87. West Virginia, 289 F.3d at 283-84. The federal estate recovery statute was designed to equalize home-owning Medicaid enrollees. People are permitted to exclude the value of their residence when calculating Medicaid qualifications; however, if the enrollee passes away and no spouse or child is living in the home, the state must obtain money from the estate of the deceased. 42 U.S.C. § 1396p(b) (2000). West Virginia already had a "spend down" requirement for 
approximately one billion dollars per year in federal Medicaid funds, and its Federal Medicaid Assistance Percentage ("FMAP") was seventy-five percent, an amount exceeded only by Mississippi ${ }^{88}$ West Virginia claimed that the federal requirement for estate recovery from deceased Medicaid beneficiaries placed a disproportionate burden on its poor citizens yet yielded a relatively small return for the federal government. ${ }^{89}$

The Fourth Circuit began its analysis by relying on the statement of the breadth of the Spending Clause power from New York v. United States, which upheld Congress's ability to provide incentives to states by offering federal money with conditions attached. ${ }^{90}$ The court noted that the limit of the Spending Clause power lies where " 'pressure turns into compulsion'" and that such federal compulsion, under New York, could be a violation of the Tenth Amendment. ${ }^{91}$ In rejecting the State's argument that the estate recovery provision was coercive and violated the Tenth Amendment, the Fourth Circuit considered whether coercion should be deemed nonjusticiable because courts cannot evaluate the financial status of states vis-à-vis the federal government. ${ }^{92}$ The court noted that the Supreme Court had not struck down an exercise of Spending Clause power since $1937^{93}$ and that no court had struck down federal legislation as undue coercion or compulsion. ${ }^{94}$ Acknowledging that the theory of coercion was still a live doctrine under Dole, the Fourth Circuit noted that the Supreme Court provided no guidance on the line between influence and compulsion, and

Medicaid qualification (meaning that all assets must be diminished) that excluded only a house, so homes are, practically speaking, the only asset to which the provision would apply. West Virginia, 289 F.3d at 284-85.

88. West Virginia, 289 F.3d at 284 n.2. The lower a state's per capita income, the higher an FMAP the state receives; thus, a poorer state might receive more Medicaid dollars than a wealthy state, but that poor state might provide fewer Medicaid services to its citizens. 42 U.S.C. $\$ 1396 \mathrm{~d}(\mathrm{~b})(2000)$. Federal Medicaid funding amounts do not translate directly into amounts of medical services for the poor, but they do indicate a greater reliance on federal dollars to provide medically necessary services to the poor in a poor state. In this case, twenty percent of West Virginia's population received medical care through Medicaid spending, compared with fifteen percent of the national population. West Virginia, 289 F.3d at 287.

89. West Virginia, $289 \mathrm{~F} .3 \mathrm{~d}$ at 285 . The West Virginia estate recovery program yielded $\$ 2.5$ million annually (actual recoveries being much lower than adjudicated amounts), and seventyfive percent of the $\$ 2.5$ million was sent to the federal government (a percentage that is tied to the state's FMAP), resulting in the federal government recovering "approximately two-tenths of onepercent of the more than $\$ 1$ billion in Medicaid funds received by the state each year." Id.

90. Id. at 286 (citing New York v. United States, 505 U.S. 144, 168 (1992)).

91. Id. (quoting South Dakota v. Dole, 483 U.S. 203, 211 (1987)).

92. Id. at 288.

93. See United States v. Butler, 297 U.S. 1, 78 (1936). In that case, the Court upheld the broad Hamiltonian view of the power to tax and spend as a separate enumerated power, but Congress's exercise of that power was held to violate the Tenth Amendment. See id. at 68-70. The Court has not exercised this reasoning since Butler. See West Virginia, 289 F.3d at 289 n.6.

94. West Virginia, 289 F.3d at 289. 
thus many courts had declared coercion a political question. ${ }^{95}$ Many of the cases cited by the Fourh Circuit involved state challenges to either Medicaid or welfare provisions that states found objectionable but that they were unable to reject for fear that safety nets would disappear without federal dollars. ${ }^{96}$ This type of argument arises again in the context of the Clawback Provision, as will be discussed below. ${ }^{97}$

Despite its acceptance of the coercion theory, the Fourth Circuit rejected West Virginia's claim for a violation of the Tenth Amendment. ${ }^{98}$ The court relied on one aspect of the conditions on spending: the federal government merely threatened to withhold all or part of West Virginia's Medicaid funds, and, because actual withholding had not occurred, the court refused to consider the argument that a complete loss of Medicaid funds would be devastating. ${ }^{99}$ Thus, the Fourth Circuit determined that the estate recovery mandate as it existed (without penalties having been exacted) was not unduly coercive and did not violate the Tenth Amendment. ${ }^{100}$

West Virginia is consistent with two cases challenging conditions of Medicaid funding, California v. United States ${ }^{101}$ and Texas v. United States. ${ }^{102}$ Both border states accused the federal government of failing to stem the flow of illegal aliens, who allegedly burdened a number of statebased services, including Medicaid; the states claimed that they were obligated to treat illegal aliens in their emergency rooms, which caused healthcare costs to escalate. ${ }^{103}$ The states alleged that initial participation in

95. Id. at 289-90.

96. Id. at 290 (citing Kansas v. United States, 214 F.3d 1196, 1202 (10th Cir. 2000)) (rejecting the idea that Temporary Assistance for Needy Families is impermissibly coercive), cert. denied, 531 U.S. 1035 (2000); Texas v. United States, 106 F.3d 661, 666 (5th Cir. 1997) (rejecting a Tenth Amendment challenge to the federal funding for treating undocumented aliens with Medicaid funding); California v. United States, 104 F.3d 1086, 1092 (9th Cir. 1997) (also rejecting a challenge to the requirement of treating illegal aliens in emergency rooms as a condition of Medicaid funding, even though the state claimed its medical system would collapse without Medicaid dollars); Oklahoma v. Schweiker, 655 F.2d 401, 414 (D.C. Cir. 1981) (rejecting the coercion argument as a sham for a "hard choice" between accepting federal funds with conditions or raising state taxes and insinuating that the coercion theory is nonjusticiable). Though the Court in Dole described the fifth element of its test as coercion becoming impermissible compulsion, many courts use the term coercion to indicate compulsion, further confusing the issue. See South Dakota v. Dole, 483 U.S. 203, 211 (1987).

97. See infra notes 235-242 and accompanying text.

98. West Virginia, 289 F.3d at 291-92.

99. Id. at 292.

100. Id. at 292.

101. 104 F.3d 1086 (9th Cir. 1997), cert. denied, 522 U.S. 806 (1997).

102. 106 F.3d 661 (5th Cir. 2000).

103. California, 104 F.3d at 1092; Texas, 106 F.3d at 666. This aspect of the states' arguments was disingenuous. As part of the Consolidated Omnibus Budget Reconciliation Act of 1985 , a provision was added to the Medicaid reimbursement rules that prevented paying for 
Medicaid was voluntary, but that they at the time of the litigation had no choice: they had to participate in Medicaid or their healthcare systems would "collapse." 104 The Fifth Circuit and Ninth Circuit were in agreement with decisions of the Second, Third, and Eleventh Circuits determining that participation in Medicaid is entirely voluntary ${ }^{105}$ and therefore could not qualify as coercion. ${ }^{106}$ The claims in these cases were somewhat creative, as the states were not truly forced by Medicaid to treat illegal aliens. Indeed, the converse is correct: states could receive Medicaid payment for treating illegal aliens in emergency rooms only in certain circumstances. ${ }^{107}$

treatment of illegal aliens unless the illegal alien presented in an emergency room and medical care was necessary for "treatment of an emergency medical condition." 42 U.S.C. $\$ 1396 \mathrm{~b}(\mathrm{v})(2)$ (2000). Undoubtedly hospitals were receiving increasing numbers of illegal aliens in their emergency rooms and, being uninsured, they likely had no means of payment. This may have created a greater burden on state emergency rooms and taxpayers, but the condition of federal funding is quite different than the states' representation. The language is notably different from, for example, the Emergency Medical Treatment and Active Labor Act ("EMTALA"), which affirmatively requires hospitals with emergency rooms that accept Medicare as reimbursement to treat all patients with emergency medical conditions (or to stabilize them before appropriate transfer). 42 U.S.C.A. \$ 1395dd (West 2003 \& Supp. 2007).

104. California, 104 F.3d at 1092; see also Texas, 106 F.3d at 666 (reporting the State's assertion that the State faced a choice between treating undocumented aliens and sacrificing public health).

105. The circuits base their assessment of the voluntary nature of Medicaid on Wilder $v$. Virginia Hospital Ass'n, 496 U.S. 498 (1990), a case in which the Court found that healthcare providers could enforce the Boren Amendment through 42 U.S.C. $\S 1983$ to compel a state to reimburse healthcare providers more for Medicaid services. See Wilder, 496 U.S. at 524. The Court's description of Medicaid as "voluntary" was not essential to the case but was background before the statement of facts. Id. at 502. That federal circuit courts ascribe substantive meaning to the passing description of Medicaid as "voluntary" seems a bit sophistic, as Wilder is not a Spending Clause decision; it is a decision regarding the statutory interpretation of the Boren Amendment. See id. at 523 (interpreting the Boren Amendment as creating a private right of action under $\S 1983$ regarding Medicaid rates). Chief Justice Rehnquist penned a dissent in which Justices O'Connor, Scalia, and Kennedy joined, a grouping explained by interpretation of the Boren Amendment, not by deviation in Spending Clause interpretation. Id. at 524-29 (Rehnquist, C.J., dissenting). In other words, the dissent believed that the Boren Amendment merely created conditions for states to participate in Medicaid, not a substantive right for Medicaid providers to pursue higher reimbursement rights. See id. at 527; see also Erwin Chemerinksy, Ensuring the Supremacy of Federal Law: Why the District Court Was Wrong in Westside Mothers v. Haveman, 12 HEALTH MATRIX 139, 146-47 (2002) (noting that "voluntary" is used to describe two separate "decisions" under Medicaid: whether to participate in the program ("voluntary" in nature) and whether to accept the conditions that come with doing so ("obligatory" because the conditions are the supreme law of the land once accepted)).

106. See Padavan v. United States, 82 F.3d 23, 29 (2d Cir. 1996) (regarding treatment of illegal aliens under Medicaid rules); New Jersey v. United States, 91 F.3d 463, 467 (3d Cir. 1996) (rejecting State's argument that the federal government coerced States into allowing aliens to participate in education and prison systems); Chiles v. United States, 69 F.3d 1094, 1096-97 (11 th Cir. 1995) (rejecting a claim that the burden of treating illegal aliens pursuant to Medicaid program rules violated a principle of guaranteed "equality among the states"), cert. denied, 517 U.S. 1188 (1996).

107. See 8 U.S.C. $\S 1611(\mathrm{~b})(1)(\mathrm{A})(2000)$; see also $\S 1396 \mathrm{~b}(\mathrm{v})(2)$. 
If their challenges were based on Medicaid conditions that actually forced states to act as a condition of receiving federal funds, then perhaps the circuit courts' interpretations of coercion would have been different.

In contrast to the Title IX cases, the Medicaid cases are based on a different aspect of spending doctrine-even if the conditions are unambiguous, they have been added to a long-standing program at a time when the state no longer feels able to reject the funding. Contrary to the Fourth Circuit's conclusion, it seems that a coercion analysis must involve the threat of removal of funds, not just the removal itself, regardless of whether a state stands to lose all or part of federal funding. Otherwise, no motivation to comply with conditions on federal funds would exist until the federal government actually withheld funds, which would be administratively inefficient (at least). The Fourth Circuit's analysis would seem to deny the theory of the deterrent effect of criminal law (and civil laws that act like criminal laws); behavior is affected by threats and conditions before they actually occur. ${ }^{108}$ West Virginia contended that the threat alone was enough to coerce the state to adhere to the estate recovery requirement, despite the requirement being detrimental to the state's most vulnerable citizens. ${ }^{109}$ Waiting until the state loses all of its federal funding seems an unnecessary extra element in analyzing federal coercion and the point at which coercion reaches compulsion.

Justice Kennedy's dissent in Davis also may be helpful, as the temporal aspect of his reading of the requirements for conditional spending could influence the continuous amending of conditions for states (and providers) that participate in Medicaid and Medicare. ${ }^{10}$ Pennhurst may be relevant, too, as provisions contained in recent amendments to Medicare are far from clear. ${ }^{111}$ However, the analyses put forth by the circuits and the Supreme Court seem to ignore the possibility that clear notice is almost irrelevant in a program that has existed for decades and that states could not leave for fear of loss of important safety nets.

108. See alan Norrie, Crime, Reason and History: a Critical Introduction to CRIMINAL LAW 198-205 (1993).

109. See West Virginia v. U.S. Dep't of Health and Human Servs., 289 F.3d 281, 294 (4th Cir. 2002).

110. Davis v. Monroe County Bd. of Educ., 526 U.S. 629, 654-58 (1999) (Kennedy, J., dissenting).

111. Some would include Rust v. Sullivan, 500 U.S. 173 (1991), in this list of healthcare/Spending Clause cases, but unconstitutional conditions cases do not fit the pattern of the unambiguous conditions/clear notice line and stand outside the trend analyzed, see id. at 195 (finding aspects of Title X's prohibition on abortion counseling in federally funded family planning services consistent with the Dole statement that the federal government has the "ancillary" power under the Spending Clause to ensure that federal funds are appropriately used). 


\section{c. The Highway Cases}

The highway cases are another example of the effect of subject characterization on decisions and divisions in the Supreme Court and of the skepticism regarding coercion theories. As noted above, the majority in Dole believed the drinking age funding condition was germane to the proper federal goal of funding highways; but, Justice O'Connor's dissent articulated the concern that an area of traditional state regulation (drinking age) that was buttressed by the Twenty-first Amendment was completely unrelated to the federal highway interest. ${ }^{112}$ Like the Medicaid/healthcare cases, the subject matter could be characterized as either a matter of federal concern (highways) or a matter of state concern (alcohol).

This type of issue arose in Nevada v. Skinner, ${ }^{113}$ a Ninth Circuit case that dealt with the national speed limit rather than the national drinking age. Nevada pertains to this conditional spending discussion because the penalty for failure to comply with the funding condition of a fifty-five mile-perhour speed limit was total loss of highway funding. ${ }^{114}$ Nevada wanted to post seventy mile-per-hour speed limits but was informed that it would lose all of its federal highway funding if it did so. ${ }^{115}$ Nevada sued the federal government, alleging that the Highway Act violated the Dole prohibition against compulsion. ${ }^{116}$ Noting that the coercion theory had never been decided in favor of a challenging state, the Ninth Circuit dismissed Nevada's assertion that a complete loss of federal funding sufficed as coercion under Spending Clause doctrine. ${ }^{117}$ The court acknowledged the difficulty of defining coerced participation in a federal program and essentially rejected the theory as an unworkable method of resolving federal-state disputes. ${ }^{118}$ The Ninth Circuit circumvented a full discussion of that line of reasoning, however, by concluding that Congress could have

112. See supra notes $44-48$ and accompanying text.

113. 884 F.2d 445 (9th Cir. 1989).

114. Id. at 446 .

115. Id.

116. Id. at 446-47. The Federal Aid Highway Act was enacted in 1916, modified in 1973 by the Emergency Highway Energy Conservation Act (which imposed the noncompliance penalty of loss of all federal highway funds), and modified again in 1987 to permit a sixty-five mile-perhour speed limit in rural areas, but maintain the penalty of full loss of federal funds for failure to adhere to conditions. See id. at 446 (citing 23 U.S.C. § 154).

117. Id. at 448 .

118. Id. This response relied in part on the theory of federalism that emerged from Garcia v. San Antonio Metropolitan Transit Authority (the Tenth Amendment is enforced by the political process and not by the courts) that is now defunct. See Garcia v. San Antonio Metro. Transit Auth., 469 U.S. 528, 552-53 (1985). Although New York v. United States, 505 U.S. 144 (1992), did not specifically overrule Garcia, the conclusion that the Tenth Amendment was enforceable by the Supreme Court rendered Garcia virtually meaningless. See ERWIN CHEMERINSKY, CONSTITUTIONAL LAW: PRINCIPLES AND POLICIES 324 (3d ed. 2006). 
enacted the Highway Act under its Commerce Clause power. ${ }^{119}$ The Ninth Circuit also concluded that even if coercion existed, the proper course of action was for the state to negotiate with Congress, not for the judiciary to protect it. ${ }^{120}$

In 2003, the Supreme Court sidestepped the opportunity to revisit Spending Clause doctrine in Pierce County v. Guillen, ${ }^{121}$ even though the Washington State Supreme Court had concluded that federal highway legislation violated the germaneness category of Dole. ${ }^{122}$ The unanimous decision written by Justice Thomas analyzed the statute as if a Commerce Clause analysis were the only jurisprudential route; however, the statute's language clearly indicated a Spending Clause foundation in that the evaluation of roads by the states was undertaken to obtain federal funding for highway improvements. ${ }^{123}$ The analysis in Guillen was similar to that in Nevada v. Skinner; even though states could lose ninety percent of their highway safety funding, the Court was reluctant to review the Spending

119. Nevada, 884 F.2d at 449-50. Even if this case had been decided after United States $v$. Lopez, 514 U.S. 549 (1995), the outcome likely would have been the same. This is supported by the decision articulated by one of the greatest Commerce Clause skeptics, Justice Thomas, in Pierce County v. Guillen, 537 U.S. 129 (2003), decided several years after Lopez and discussed below.

120. See id. at 452-53. The Ninth Circuit used the understanding of the Tenth Amendment and principles of federalism that were in force after the reversal of National League of Cities $v$. Usery, 426 U.S. 833 (1976), by Garcia, but before the decisions in New York and Lopez. See generally Usery, 426 U.S. 833 (1976), overruled by Garcia v. San Antonio Metro. Transit Auth., 469 U.S. 528 (1985); New York v. United States, 505 U.S. 144 (1992); United States v. Lopez, 514 U.S. 549 (1995).

121. 537 U.S. 129 (2003).

122. See Guillen v. Pierce County, 31 P.3d 628, 651 (Wash. 2001). The Washington Supreme Court stated:

[W]e must decide whether the Spending Clause authorizes Congress to bar state courts from permitting discovery of accident reports and other traffic and accident materials ... prepared for state and local purposes, simply because those ... are also "collected" and used for federal purposes .... While the Spending Clause entitles Congress to offer states the option of accepting federal funds "with strings attached" ... the United States Supreme Court has made it clear that Congress may do so only if those "strings" are also firmly "attached" to a legitimate federal interest in a specific federal project or program. ... We find that no valid federal interest in the operation of the federal safety enhancement program is reasonably served by barring the admissibility and discovery in state court of accident reports and other traffic and accident materials and "raw data" that were originally prepared for routine state and local purposes, simply because they are "collected" for . . . federal purposes pursuant to a federal statute.

Id. (quoting South Dakota v. Dole, 483 U.S. 203, 208 (1987)). The Washington Supreme Court also rejected the regulations as a permissible exercise of the Commerce Clause power based on its interpretation of Hodel v. Indiana, 452 U.S. 314 (1981). See Guillen, 31 P.3d at 653-54.

123. See 23 U.S.C. $\S 152$ (2000) (requiring states to conduct regular surveys of road hazards to receive federal funding). 
Clause aspect of the legislation when the Commerce Clause was also a basis for Congress's actions. ${ }^{124}$

To recapitulate, a pattern in Spending Clause jurisprudence emerged from the initial doctrine enunciated in Pennhurst, which was enhanced by Dole. The Court in Pennhurst deemed Spending Clause legislation to be in the nature of a contract, and this meant that states must understand any conditions placed on spending, creating the requirement of what the Court would label "unambiguous conditions." 25 Pennhurst was enhanced by three to four additional categories of limitations on federal funding legislation as enunciated in Dole, the most important of which may be the unenumerated fifth category prohibiting coercion or compulsion. ${ }^{126}$ The Dole decision led to a number of Spending Clause legislation cases in which the majority of the Court, often led by Justice O'Connor, found that unambiguous conditions as articulated in Pennhurst did not require more from Congress than "adequate" or "sufficient" notice. In other words, Congress was not required to make specific statutory proclamations for conditions on spending statutes to be enforceable, allowing conditions on federal spending to be read quite broadly. Dissenters consistently responded, however, that Pennhurst required the statute itself to provide states with "clear notice" of any conditions on spending. At the same time, federal courts were unwilling to adjudicate the possibility of coercion in federal spending, which has created a gap in the Spending Clause line of cases. If a state has had adequate notice, and it cannot be coerced, then conditions on spending would almost never be unconstitutional. With the adequate notice majorities and clear notice dissents switching places in Arlington, this situation may be coming to an end.

\section{B. Arlington-A Spending Clause Benchmark}

Arlington received relatively little press and appears to be overlooked (thus far) as a noteworthy decision from the first term of the Roberts

124. See Guillen, 537 U.S. at 146-47 (analyzing the Federal Highway Safety Act under the second Lopez category-regulation of the instrumentalities of interstate commerce-and finding that Congress acted within its Commerce Clause power). The opinion relegates the Spending Clause to a footnote, stating. "Because we conclude that Congress had authority under the Commerce Clause ... we need not decide whether [the statute] could also be a proper exercise of Congress' authority under the Spending Clause ..." Id. at 147 n.9. Some observers have theorized that the succinct opinion in Guillen was the result of the Rehnquist quest to separate legislation that was traditionally the province of the states from legislation that was traditionally the province of the federal government. See Lynn A. Baker, Federalism and the Spending Power from Dole to Birmingham Board of Education, in THE REHNQUIST LEGACY, supra note 33, at 205, 218 (seeking consistency in post-Dole Spending Clause jurisprudence in the context of Chief Justice Rehnquist's "legacy for federalism").

125. See supra notes $22-24$ and accompanying text.

126. See supra notes $40-42$ and accompanying text. 
Court. ${ }^{127}$ The Court afforded a view of its new chemistry in Arlington and demonstrated that it does not feel beholden to the Spending Clause reasoning developed from Pennhurst and Dole.

\section{Context for Arlington}

Arlington considered the Individuals with Disabilities Education Act (the "IDEA"), which encourages equal access to public education for children with disabilities by giving states federal funds and providing a private cause of action for students who have not been afforded the access required by the IDEA. ${ }^{128}$ Congress first enacted the statute in 1970 and has re-adopted and overhauled it with regularity; ${ }^{129}$ one of the amendments created a fee-shifting provision, which was added via the Handicapped Children's Protection Act of 1986. ${ }^{130}$ The goals of the IDEA are to ensure that children with disabilities have access to a "free appropriate public education," that minority students are properly diagnosed and educated, and that more minorities can enter the teaching profession. ${ }^{131}$ Its centerpiece is the requirement for an Individualized Education Program ("IEP"), a discrete plan for educating each disabled student that must exist to fulfill the terms of the IDEA. ${ }^{132}$ Parents who are dissatisfied with the IEP or its implementation have administrative remedies that ultimately lead to court. ${ }^{133}$ If parents successfully challenge an IEP, the fee-shifting provision becomes relevant; it provides "reasonable attorneys' fees as part of the costs to the parents of a child with a disability ...."134 Because the statute is designed to address inequalities in education and because it provides for federal funding, its constitutional basis is twofold: the Spending Clause and Section Five of the Fourteenth Amendment. ${ }^{135}$

127. For example, U.S. Law Week issues a Term in Review volume that lists the "significant cases" of the term divided by civil cases and criminal cases. The 2005-06 Term in Review does not list Arlington as an important case. See Term in Review, 75 U.S. LAW WEEK 3049-60 (2006) (showing Arlington in a subject matter list of civil cases from the 2005-06 term and listing the case as a disability case).

128. 20 U.S.C. $\$ 1415(\mathrm{i})(2)(2000)$.

129. 20 U.S.C.A. $\$ 1400$ (West 2003 \& Supp. 2007).

130. See Handicapped Children's Protection Act of 1986, Pub. L. No. 99-372, § 2,100 Stat. 796, 796-97 (1986) (no current enacted sections other than those incorporated into 20 U.S.C. $\S \S 1400-82(2000))$.

131. 20 U.S.C. $\$ 1400$ (c), (d) (2000).

132. Id. $\$ 1414$.

133. Id. $\$ 1415(\mathrm{i})$.

134. $\S 1415(\mathrm{i})(3)(\mathrm{B})$.

135. See Smith v. Robinson, 468 U.S. 992, 1009-10 (1984) (noting that the Education of the Handicapped Act, the precursor to the IDEA, was based upon Equal Protection Clause powers and was "not simply a funding statute"), superseded by statute, 20 U.S.C. $\$ \$ 1400-82$ (2000); see also Arlington Cent. Sch. Dist. Bd. of Educ. v. Murphy, 548 U.S. 126 S. Ct. 2455,2458 (2006) (Ginsburg, J., concurring) (noting that the IDEA is founded on Section 5 of the Fourteenth 
In Arlington, the parents of a disabled child hired a special education expert to facilitate their lawsuit against the Arlington Central School District, in which they alleged that the district did not institute a proper IEP for their son. ${ }^{136}$ After a number of administrative hearings in which they proceeded pro se, the parents prevailed and sought reimbursement from the school district for $\$ 29,350$ in expert fees. ${ }^{137}$ Though the IDEA provides for recovery of attorneys' fees, it does not directly address the use of educational consultants or other experts. ${ }^{138}$ Thus, the question before the Court was whether the trial court properly awarded expert fees to the prevailing family, an issue that had divided a handful of federal appellate courts. ${ }^{139}$

The Second Circuit held that the Murphy family was entitled to recover expert fees based on the language and history of the IDEA and Supreme Court dicta. ${ }^{140}$ The decision parsed the meaning of the IDEA, studied the Conference Committee report for the revision of the IDEA that added fee-shifting to the statute, and determined that the statute should be read to award expert fees in addition to attorneys' fees. ${ }^{141}$ The lower court did not analyze the Spending Clause, however, nor was the Spending Clause implicated by any of the decisions of the circuits that had considered the same issue. ${ }^{142}$ According to the respondent's oral argument at the Supreme Court, no federal IDEA decision, in twenty years of IDEA caselaw, was founded on a Spending Clause analysis. ${ }^{143}$ Likewise, the

Amendment and the Spending Clause in describing her break from the majority in its reliance on Spending Clause analysis).

136. Arlington, 548 U.S. at 126 S. Ct. at 2458.

137. Id.

138. See $§ 1415(\mathrm{i})(3)$.

139. Arlington, 548 U.S. at $126 \mathrm{~S}$. Ct. at 2458 ; see infra note 142.

140. See Murphy v. Arlington Cent. Sch. Dist. Bd. of Educ., 402 F.3d 332, 336-37 (2d Cir. 2005) (citing W. Va. Univ. Hosps., Inc. v. Casey, 499 U.S. 83, 111 (1991)) (relying in part on dicta written by Justice Scalia in Casey, which described the grant of costs in the IDEA within the context of legislative history that indicated an intent to award fees for experts as well as attorneys), cert. granted, 546 U.S. 1085 (2006).

141. Id.

142. See Neosho R-V Sch. Dist. v. Clark ex rel. Clark, 315 F.3d 1022, 1031-32 (8th Cir. 2003) (holding that the IDEA, as a matter of statutory interpretation, does not permit recovery of expert fees because the statute explicitly provides for attorney fee shifting only, even though the language of the statute indicates that Congress intended more than attorney fee recovery); T.D. v. LaGrange Sch. Dist. No. 102, 349 F.3d 469, 481-82 (7th Cir. 2003) (agreeing with the reasoning of the Eighth Circuit and holding that the IDEA does not permit recovery of expert witness fees). By the time petitions for certiorari reached the Supreme Court in Arlington, the Court of Appeals for the District of Columbia also weighed in and agreed with the reasoning of the Seventh and Eighth Circuits. See Goldring v. District of Columbia, 416 F.3d 70, 73 (D.C. Cir. 2005), cert. denied, 548 U.S. 126 S. Ct. 2985 (2006).

143. See Transcript of Oral Argument at 35-37, Arlington, 548 U.S. 126 S. Ct. 2455 (2006) (No. 05-18). In the course of parsing the ambiguities of the IDEA's fee-shifting language 
Supreme Court cases to which the circuits drew analogies did not employ constitutional analyses; instead, the decisions depended on statutory interpretation. ${ }^{144}$

Each of the circuits that had addressed the issue found sufficient language in the IDEA to determine whether expert fees could be awarded without resorting to a Spending Clause analysis. ${ }^{145}$ The Second Circuit considered legislative history and reached the position that expert fees were included in the fee-shifting language: "award reasonable attorneys' fees as part of the costs ...."146 The Seventh and Eighth Circuits each analyzed the IDEA by reviewing the plain language of other fee-shifting federal

and the desirability of relying on legislative history, Chief Justice Roberts asked Mr. Vladeck, counsel for the respondent, what ambiguities that require reliance on legislative history would do to the statute in light of its enactment under the Spending Clause. Id. at 35. Chief Justice Roberts expressed concern that states would not have had notice that they were expected to pay expert fees, a condition that the statute would have to set forth "unambiguously" for the condition to be valid, according to the Chief Justice, under Pennhurst. Id. Mr. Vladeck responded that the legislative history provided the notice that states needed and noted that "[n]o Spending Clause argument has ever been raised in this kind of issue even though the statute has been on the books for 20 years." Id. at 37.

144. See W. Va. Univ. Hosps., Inc. v. Casey, 499 U.S. 83, 92 (1991), superseded by statute, 42 U.S.C. $\S 1988$ (c) (2000). The Supreme Court held as a matter of statutory interpretation that $\S 1988$, the Civil Rights Attorney's Fees Awards Act, did not allow a victorious plaintiff to recover expert fees because the statute at the time of the decision did not explicitly allow for expert fees and because the implicit understanding of attorneys' fees at the time $\$ 1988$ was drafted did not include expert fees in addition to attorneys' fees. Id. at 89-92. In short, the issue was the fee-shifting language in a statutory scheme, not the Spending Clause; the dissenters also did not go beyond statutory interpretation. Id. at 102-16 (Marshall, J., dissenting); see also Crawford Fitting Co. v. J.T. Gibbons, Inc., 482 U.S. 437, 439 (1987) (parsing federal rules regarding fee shifting and barring expert fees from being included in federal awards of costs "absent contract or explicit statutory authority").

145. The circuit court decisions were determined in a manner consistent with the prudential ideal of refraining from deciding a constitutional issue when other grounds exist for resolution. The doctrine of constitutional avoidance is grounded in the assumption that Congress intends to legislate in compliance with the Constitution. Therefore, there is a preference for interpreting a statute solely considering its words, even if the text can have a number of different meanings, based on the premise that Congress would not intend an unconstitutional interpretation. See Clark v. Martinez, 543 U.S. 371, 381-82 (2005) (describing the contours of the doctrine of constitutional avoidance); Harmon v. Brucker, 355 U.S. 579, 581 (1958) (observing a "duty to avoid deciding constitutional questions presented unless essential to proper disposition of a case"); Spector Motor Serv. v. McLaughlin, 323 U.S. 101, 105 (1944) ("If there is one doctrine more deeply rooted than any other in the process of constitutional adjudication, it is that we ought not to pass on questions of constitutionality ... unless such adjudication is unavoidable."); Ashwander v. Tenn. Valley Auth., 297 U.S. 288, 345-48 (1936) (Brandeis, J., concurring) (describing the history of and necessity for the doctrine of constitutional avoidance); Crowell $\mathrm{v}$. Benson, 285 U.S. 22, 62 (1932) ("[I]t is a cardinal principle that this Court will first ascertain whether a construction of the statute is fairly possible by which the [constitutional] question may be avoided." (footnote omitted)); Burton v. United States, 196 U.S. 283, 295 (1905) ("It is not the habit of the court to decide questions of a constitutional nature unless absolutely necessary to a decision of the case.").

146. Arlington, 402 F.3d at 335-37. 
statutes that would have applied in the absence of specific language in the IDEA. ${ }^{147}$ The Eighth Circuit was the first to adjudicate whether expert witness fees could be included in the definition of costs, and, finding no specific language in the IDEA itself, the court relied on general provisions of the United States Code. ${ }^{148}$ It also relied on the Supreme Court's interpretation of federal statutory fee-shifting provisions and held that expert fees could not be recovered under the doctrine established in Crawford Fitting Co. v. J.T. Gibbons, Inc. ${ }^{149}$ The Seventh Circuit essentially adopted the reasoning of the Eighth Circuit. ${ }^{150}$ The D.C. Circuit weighed in while the Murphys' petition for certiorari was being considered, and that circuit's reasoning and holding were consistent with the Seventh and Eighth Circuits. ${ }^{151}$

\section{Reaching Beyond the Circuits-Arlington at the Supreme Court}

The Supreme Court cast its analysis in Arlington as "guided" by the Spending Clause. ${ }^{152}$ Citing Dole, Justice Alito described Spending Clause

147. See Neosho, 315 F.3d at 1031-32; LaGrange Sch. Dist. No. 102, 349 F.3d at 480-82.

148. Neosho, 315 F.3d at 1031 (relying on 28 U.S.C. $\S 1920(3)$ (2000) and 28 U.S.C. $\S 1821(\mathrm{~b})(2000))$.

149. Id. (citing Crawford Fitting Co., 482 U.S. at 445).

150. See LeGrange Sch. Dist. No. 102, 349 F.3d at 481.

151. See Goldring v. District of Columbia, 416 F.3d 70, 73 (D.C. Cir. 2005) (discussing the circuit split and finding the no-expert fees decisions persuasive), cert. denied, 548 U.S. —, 126 S. Ct. 2985 (2006). The Goldring court incorporated a related Third Circuit decision into its acknowledgement of the circuit split. See id. (citing Arons v. N.J. Bd. of Educ., 842 F.2d 58, 62 (3d Cir. 1988)). The Second Circuit also discussed Arons in its determination that expert fees could be awarded, see Arlington, 402 F.3d at 338-39, but it was not considered by the other circuits, perhaps because Arons is specific to the denial of legal fees to a non-lawyer expert (although Arons noted that expert fees could be awarded for the time the expert spent as an expert rather than performing tasks of a legal nature without a license to practice law). See Arons v. N.J. Bd. of Educ., 842 F.2d 58, 62 (3d Cir. 1988); see also Neosho, 315 F.3d at 1031 (stating "our research indicates that no circuit court has yet ruled on the issue"); LaGrange Sch. Dist. No. 102, 349 F.3d at 481 (deeming Neosho the first circuit court decision on awarding expert fees under the IDEA). It has been suggested that the Eighth Circuit simply missed Arons and that the Seventh Circuit therefore missed it as well. See Kathryn H. Crary, Comment, Necessary Expertise: Allowing Parents To Recover Expert Witness Fees Under the Individuals with Disabilities Education Act, 77 TEMP. L. REv. 967, 980 n.123 (2004). The Supreme Court did not mention Arons in its string cite regarding the circuit split. See Arlington Cent. Sch. Dist. Bd. of Educ. v. Murphy, 548 U.S. 126 S. Ct. 2455, 2458 (2006). This was so despite the interesting fact that the expert in question in Arlington was the same expert involved in Arons. The seemingly logical conclusion is that the issue is being drawn more narrowly by some federal courts than by others, which would account for Arons's sporadic appearance.

152. Arlington, 548 U.S. at 126 S. Ct. at 2458 (citing Schaffer v. Weast, 546 U.S. 49 (2005)). Justice O'Connor began the IDEA analysis in Schaffer by stating that the IDEA "is a Spending Clause statute that seeks to ensure" equal educational access for students with disabilities. Schaffer v. Weast, 546 U.S. 49, 51 (2005). This statement was merely descriptive, as the analysis was grounded in statutory interpretation. Id. at 56-57. 
power as "broad," 153 but noted that conditions placed on spending must be stated "unambiguously" by Congress pursuant to Pennhurst. ${ }^{154}$ The Court also returned to the contract analogy set forth in Pennhurst. ${ }^{155}$ The Court placed a state-oriented lens over its analysis, declaring that its perspective must be that of a state agreeing to receive federal funds and entering a contract with the federal government, which creates a need for the state to understand all of the conditions that attach to the funds. ${ }^{156}$ Justice Alito stated that the Court must consider whether a state official "would clearly understand that one of the obligations of the Act is the obligation to compensate prevailing parents for expert fees."157 Justice Alito then adopted the language of Justice Kennedy's dissent in Davis: "In other words, we must ask whether the IDEA furnishes clear notice regarding the liability at issue in this case." 158

Using the "viewpoint of the state" and the "clear notice" model, the Court sought to determine whether New York had clear notice regarding fee shifting for experts, requiring the Court to interpret the statutory language of the IDEA. ${ }^{159}$ The Court explored the "plain meaning" of the language regarding fee shifting and determined that Congress must include specific language awarding expert fees if it intends the prevailing party to receive them. ${ }^{160}$ Contrary to Justice O'Connor in the Title IX cases, Justice Alito was not swayed by legislative history that strongly indicated intent to provide for more than just attorneys' fees or by the argument that language within the statute indicated "costs" means something more than attorneys' fees. ${ }^{161}$ The clear notice standard dictated that the plain meaning of the statute's terms could only permit attorneys' fees, to the exclusion of expert expenses.

153. Arlington, 548 U.S. at 126 S. Ct. at 2459 (citing South Dakota v. Dole, 483 U.S. 203, 206-07 (1987)).

154. Id. at _, 126 S. Ct. at 2459 (citing Pennhurst State Sch. \& Hosp. v. Halderman, 451 U.S. $1,17(1981))$.

155. Id.; see also Barnes v. Gorman, 536 U.S. 181, 186 (2002) (in which the contract analogy was strongly endorsed).

156. Arlington, 548 U.S. at $126 \mathrm{~S} . \mathrm{Ct}$. at 2459.

157. Id.

158. Id.

159. The parties did not brief the case based on the Spending Clause. Their focus was statutory interpretation and legislative history. The United States' amicus brief, however, did briefly note the foundational Spending Clause principles. See Brief for the United States as Amicus Curiae on Petition for Writ of Certiorari at 12, Arlington, 548 U.S. 126 S. Ct. 2455 (2006) (No. 05-18). Relying in part on the background statement from Schaffer v. Weast, 546 U.S. 49 (2005), the United States noted that the IDEA is Spending Clause legislation and thus must set forth conditions on spending "unambiguously." Brief for the United States as Amicus Curiae on Petition for Writ of Certiorari, supra (citing Barnes, 536 U.S. at 186).

160. Arlington, 548 U.S. at , $126 \mathrm{~S}$. Ct. at $2459-61$.

161. See id. at $126 \mathrm{~S}$. Ct. at 2459-63. 
The dissenters' positions in Title IX cases predating the Roberts Court indicated that this change was possible. ${ }^{162}$ The clear notice requirement, as opposed to Justice O'Connor's "adequate notice" or "sufficient notice," had been advocated strongly by Justice Kennedy in his Davis dissent. ${ }^{163}$ With the architects of the Spending Clause jurisprudence no longer on the bench, the moment arrived to steer toward the dissent's preference for more substantial legislative language.

Both the concurrence and the dissents in Arlington noted the deviation from precedent. ${ }^{164}$ Justice Ginsburg's partial concurrence underlined the freshly articulated language of "clear notice" and the Court's reliance on Pennhurst. ${ }^{165}$ Justice Ginsburg was troubled that Pennhurst's language was used out of context, and she believed that it was misplaced in light of the history of Arlington and other IDEA cases. ${ }^{166}$ Her concurrence noted that the Court's concern in Pennhurst focused on the creation of an entirely new programmatic condition that the state could not have anticipated. ${ }^{167}$ Here, however, states could see that costs in addition to attorneys' fees were contemplated by the language of the statute. ${ }^{168}$ Ultimately, Justice Ginsburg agreed with the majority that federal legislation requires a clear statement from Congress regarding fee shifting for expert fees to be awarded, but she disagreed with the Court's newly articulated and strengthened clear notice requirement. ${ }^{169}$

162. See Ilya Somin, A False Dawn for Federalism: Clear Statement Rules After Gonzales v. Raich, 2006 CATO SuP. CT. REV. 113, 131 (noting Justice Kennedy's dissent in Davis).

163. See supra notes $60-65$ and accompanying text.

164. This was not a unanimous decision, despite Justice Roberts's efforts to the contrary in his first term. See generally Lori Ringhand, The Roberts Court: Year 1, 73 TENN. L. REV. 607 (2007) (reviewing Chief Justice Roberts's efforts to achieve unanimity during his first term).

165. Arlington, 548 U.S. at 126 S. Ct. at 2464 (Ginsburg, J., concurring).

166. Justice Ginsburg's concurrence stated:

The Court extracts from Pennhurst ... a "clear notice" requirement, and deems it applicable in this case because Congress enacted the [IDEA], as it did the legislation at issue in Pennhurst, pursuant to the Spending Clause. That extraction, in my judgment, is unwarranted. Pennhurst's "clear notice" requirement should not be unmoored from its context. The Court there confronted a plea to impose "an unexpected condition for compliance-a new [programmatic] obligation for participating States."

Id. (citing Bell v. New Jersey, 461 U.S. 773, 790 n. 17 (1983)).

167. Arlington, 548 U.S. at , $126 \mathrm{~S}$. Ct. at 2464.

168. Id. Justice Ginsburg also noted that the IDEA was based in part on the congressional authority created by Section 5 of the Fourteenth Amendment and reasoned that a statute that relies in part on Section 5 should not be limited by the Spending Clause doctrine articulated by the majority. Id. at $126 \mathrm{~S}$. Ct. at $2464-65$.

169. Justice Ginsburg was persuaded by the Court's reliance on West Virginia University Hospitals, Inc. v. Casey, 499 U.S. 83 (1991), and Crawford Fitting Co. v. J.T. Gibbons, Inc., 482 U.S. 437 (1987), which found that federal statutes must expressly state the fees that are being shifted or be superseded by general federal statutes governing fee shifting in federal cases. Arlington, 548 U.S. at , $126 \mathrm{~S}$. Ct. at 2465. 
Justice Breyer's dissent focused on the meaning of "costs" within the context of the statute, its language, history, and related statutes. ${ }^{170}$ Justice Breyer noted that every person in Congress appeared to understand that "costs" included expert fees in addition to attorneys' fees and that no member of Congress objected to this understanding. ${ }^{171}$ More importantly, the dissent noted that the Court historically resolved IDEA questions "without reference to the Spending Clause or any 'clear statement rule.' "172 Not only did the Court inappropriately rely on the Spending Clause, but its interpretation of the clear notice requirement was doctrinally unworkable given that Congress had never before been held to the standard of ensuring that every detail of a condition placed on spending be in the plain language of a statute. ${ }^{173}$ Justice Breyer observed that Pennhurst does not require absolute textual clarity; instead, the basic question the Court should ask is whether states would have accepted the federal funds if they had known the "nature" of the conditions placed on receipt of the money. ${ }^{174}$ Thus, Justice Breyer interpreted Pennhurst as requiring notice regarding statutory purpose rather than clear notice as to every statutory condition in the text of the legislation. ${ }^{175}$

The clear notice requirement of the Arlington majority has many potential implications. For instance, if the Court is turning to a more limited understanding of Congress's ability to place conditions on federal spending, it is possible that the flip side of this shift will be judicial protection of the states from overreaching conditional spending under the Tenth Amendment. ${ }^{176}$ Also, any change in Spending Clause jurisprudence will have an effect on federal healthcare programs, with the real question being when and how long-term major programs such as Medicare and Medicaid will be affected. The next section will examine the possible changes through the example of the Clawback Provision.

170. Arlington, 548 U.S. at 126 S. Ct. at 2466 (Breyer, J., dissenting). Justice Souter also briefly dissented to emphasize the difference between Arlington and Barnes v. Gorman, 536 U.S. 181 (2002). Arlington, 548 U.S. at $126 \mathrm{~S}$. Ct. at 2466 (Souter, J., dissenting).

171. Arlington, 548 U.S. at , 126 S. Ct. at 2468 (Breyer, J., dissenting).

172. Id. at —, $126 \mathrm{~S}$. Ct. at 2470.

173. See id. at, $126 \mathrm{~S}$. Ct. at $2470-71$.

174. Id. at —, $126 \mathrm{~S}$. Ct. at 2471.

175. Id.

176. Admittedly, the Court has not considered the Tenth Amendment to be a limitation on the Spending Clause in many years. See generally Oklahoma v. U.S. Civil Serv. Comm'n, 330 U.S. 127 (1947) (discussing the interaction of federal conditions on spending and the Tenth Amendment). 


\section{IMPACT OF SPENDING CLAUSE JURISPRUDENTIAL MODIFICATIONS}

Though we tend to overlook it, a stratum of constitutional law overlays federal healthcare programs. Changes in Spending Clause jurisprudence could have a number of implications for federal healthcare programs from a programmatic perspective, an individual entitlement and enforcement perspective, and a healthcare fraud perspective. This section will explore one example, the Clawback Provision, to render the contours of Arlington and its implications more palpable.

\section{A. Constitutional Foundations for Federal Healthcare Programs}

The Supreme Court has recognized recently that, although traditionally the province of the states under their police power, the federal government does have the power to create national standards for "health and safety." 177 Even though the Commerce Clause has long been the source of much of Congress's power to enact legislation, ${ }^{178}$ in the

177. See Gonzales v. Oregon, 546 U.S. 243, 271 (2006) (citing Gonzales v. Raich, 545 U.S. 1 , 9 (2005) (upholding the use of the Controlled Substances Act to prevent prescription of medical marijuana as a proper exercise of Commerce Clause power)) (noting that the Controlled Substances Act is an example of Congress's ability to regulate medical issues but that it primarily serves the limited purpose of preventing diversion of controlled substances).

178. For example, the Controlled Substances Act, Comprehensive Drug Abuse Prevention and Control Act of 1970, Pub. L. No. 91-513, 84 Stat. 1242 (codified as amended in scattered sections of 21 U.S.C.), recently explicated in Gonzales v. Raich, 545 U.S. 1 (2005), and Gonzales v. Oregon, 546 U.S. 243 (2006), is a use of Congress's Commerce Clause power to regulate local activities having a substantial effect on interstate commerce. The Freedom of Access to Clinic Entrances Act, 18 U.S.C. $\$ 248$ (2000), is another example; though the Supreme Court has not spoken to it, every circuit that has heard a challenge to its constitutionality has held that Congress properly regulated access to reproductive health clinics as a function of its ability to regulate interstate commerce. See Norton v. Ashcroft, 298 F.3d 547, 551 (6th Cir. 2002), cert. denied, 537 U.S. 1172 (2003); United States v. Gregg, 226 F.3d 253, 262-63 (3d Cir. 2000), cert. denied, 532 U.S. 971 (2001); United States v. Hart, 212 F.3d 1067, 1074 (8th Cir. 2000), cert. denied, 531 U.S. 1114 (2001); United States v. Weslin, 156 F.3d 292, 296 (2d Cir. 1998), cert. denied, 525 U.S. 1071 (1999); Hoffman v. Hunt, 126 F.3d 575, 588 (4th Cir. 1997), cert. denied, 523 U.S. 1136 (1998); United States v. Bird, 124 F.3d 667, 682 (5th Cir. 1997), cert. denied, 523 U.S. 1006 (1998); Terry v. Reno, 101 F.3d 1412, 1418 (D.C. Cir. 1996), cert. denied, 520 U.S. 1264 (1997); United States v. Soderna, 82 F.3d 1370, 1373-74 (7th Cir. 1996), cert. denied sub nom., Hatch v. United States, 519 U.S. 1006 (1996); United States v. Dinwiddie, 76 F.3d 913, 919 (8th Cir. 1996), cert. denied, 519 U.S. 1043 (1996); United States v. Wilson, 73 F.3d 675, 683 (7th Cir. 1995), cert. denied, 519 U.S. 806 (1996); Cheffer v. Reno, 55 F.3d 1517, 1520-21 (11th Cir. 1995). Elements of the Health Insurance Portability and Accountability Act of 1996 ("HIPAA"), Pub. L. No. 104-191, 110 Stat. 1936 (codified as amended in scattered sections of 42 U.S.C.), especially the privacy regulations associated with HIPAA, rely on Congressional regulation of interstate commerce. See Kevin Outterson, Healthcare, Technology and Federalism, 103 W. VA. L. REV. 503, 504-05 (2001) (observing that state police power was once the greatest source of healthcare regulation and noting that the Spending Clause has given the federal government an enormous source of preemptive power in healthcare). Additionally, Congress formed the Food and Drug Administration, which is charged with investigating and enforcing the safety and efficacy of food, drugs, medical devices, and cosmetics, under the aegis 
healthcare arena, more often than not, the source of Congress's power is the Spending Clause. Most of the major federal healthcare programs rely on Congress's ability to spend for the general welfare and to place conditions on the use of that money, including Medicare and Medicaid. ${ }^{179}$

Medicare is a social insurance program that the federal government funds and administers, ${ }^{180}$ and it currently serves approximately forty-four million Americans, accounting for about fourteen percent of the federal budget. ${ }^{181}$ Medicare does not discriminate based on income or other qualifying category, ${ }^{182}$ anyone who has paid into the Social Security system for forty quarters and who reaches the age of sixty-five is automatically enrolled in the hospital insurance portion of Medicare, labeled Part A, and is immediately eligible for other aspects of Medicare (physician benefits called Part B and drug benefits dubbed Part D). Medicare has always funneled administration to private entities, now called Contractors, that run the Medicare enrollment and reimbursement functions for the federal government within designated geographic regions. ${ }^{183}$ Medicare is funded by payroll taxes, general revenue, and cost-sharing by Medicare

of the Commerce Clause. See 21 U.S.C. $\S 331$ (a)-(c) (2000) (stating that Congress's ability to pass the statute is based on the power to regulate interstate commerce).

179. See Outterson, supra note 178, at 517-20 (sharing other examples of conditioned healthcare spending such as the Hill-Burton Act (federal hospital dollars that dictated construction and charity care standards), the National Health Planning and Resources Development Act (now-defunct statutory exchange of federal dollars for adoption of certificate of need programs in states), and Medicare and Medicaid conditions of participation (rules that attend the acceptance of federal healthcare reimbursement include operational and licensure-type standards)).

180. See Social Security Amendments of 1965, Pub. L. No. 89-97, 79 Stat. 286 (codified as amended in scattered sections of 42 U.S.C.). Some argue that Medicare has the features of both a social insurance program and a social welfare program. See Dean M. Harris, Beyond Beneficiaries: Using the Medicare Program To Accomplish Broader Public Goals, 60 WASH. \& LEE L. REv. 1251, 1297-98 (2003) (relaying the Supreme Court's description of one Part of Medicare as a social insurance program and another Part of Medicare as a form of welfare).

181. See THE HENRY J. KAISER FAMILY FOUND., MEDICARE FACT SHEET 1 (2006), available at http://www.kff.org/medicare/upload/1066-09.pdf; see also CTR. ON BUDGET AND POLICY PRIORITIES, THE NuMBer OF UNINSUREd AMERICANS IS AT AN ALL-Time High 1-5 (2006), available at http://www.cbpp.org/8-29-06health.pdf (describing Census Bureau results for 2005 and providing information regarding the proportion of the population that receives health insurance from different sources in addition to statistics on the uninsured).

182. However, under the MMA, Medicare Part B beneficiaries will pay premiums that increase in accordance with the beneficiary's income for the first time in Medicare's history starting in 2007. See 42 U.S.C.A. § 1395r(i) (West Supp. 2007); see also Higher-Income Medicare Beneficiaries To Pay Higher Part B Premiums Next Year, KaISER DaILY HEALTH POL'Y REP. (The Henry J. Kaiser Family Found., Menlo Park, Calif.), Sept. 11, 2006, available at http://www.kaisernetwork.org/daily_reports/print_report.cfm?DR_ID=39713\&dr_cat=3.

183. See 42 U.S.C.A. $§ 1395 k k-1$ (West Supp. 2007). 
beneficiaries that varies depending on the particular part of Medicare being used. ${ }^{184}$

Medicaid has been described as the largest direct transfer of funds from the federal government to states' treasuries. ${ }^{185}$ Medicaid is a welfare program for "poor plus" Americans, meaning that a person must fit within a category of "deserving" poor and meet financial qualifications to receive Medicaid benefits. ${ }^{186}$ Medicaid is jointly funded by the federal government and the states, meaning the federal government sets aside funds from the general revenue and provides grants to each state that chooses to participate in Medicaid pursuant to a formula known as the Federal Medical Assistance Percentage ("FMAP"). ${ }^{187}$ Under the FMAP, the federal government matches state dollars spent on Medicaid recipients after taking into account the per capita income of the state. ${ }^{188}$ Thus, for example, a state like Mississippi with a large Medicaid population receives more Medicaid funding per capita than other states, even though it spends less money than a state like New York that also has a large Medicaid population, because the Mississippi population overall is very poor. ${ }^{189}$ Medicaid is administered by the states, each of which has its own version of the Medicaid program

184. See id. $\S 1395$ c (West 2003) (delineating eligibility for the premium-free Hospital Insurance benefit of Medicare Part A); id. $\$ 1395 \mathrm{i}-2$ (West 2003) (describing processes for enrollment in Medicare hospital insurance and premiums to be paid for individuals otherwise ineligible for Part A); id. § 1395r (West 2003) (Part B premium calculation); id. § 13951 (West 2003) (calculation of other Part B cost-sharing amounts); id. § 1395w-113 (West Supp. 2007) (Part D premium guidelines); id. §1395w-102 (West Supp. 2007) (Part D cost-sharing calculations). More specifically, the Part A hospital benefit is paid by a small, society-wide payroll tax paid by both employers and employees, interest, and minimal cost sharing by the beneficiary; the Part B physician benefit is funded about seventy-four percent by general revenue and about twenty-five percent by beneficiary premiums, the remainder being funded by interest; the Part $D$ drug benefit is financed by general revenue, beneficiary premiums, and payments from the states for dual eligibles known as the Clawback Provision, which will be discussed below. The Clawback Provision is projected to cover about eleven percent of the cost of the Part D drug benefit. See The Henry J. Kaiser Family Found., MediCare Chartbook § 7, at 60, 62 (3d ed. 2005), available at http://www.kff.org/medicare/7284.cfm.

185. See Bipartisan Commission on Medicaid Act of 2005, S. Res. 338, 109th Cong. (2005). This bill included a series of statistical findings regarding Medicaid and included an attempt to prevent the provisions of the Deficit Reduction Act of 2005 ("DRA") that altered the nature of the Medicaid program (and, reading between the lines, to advocate repeal of the Clawback to protect state Medicaid programs and dollars). The commission's suggestions were not incorporated into the DRA.

186. See 42 U.S.C. $\$ 1396 a(a)(10)(A)(i)$ (2000) (identifying categories of deserving poor, such as those who are blind, disabled, pregnant, female, elderly, or children).

187. See id. $\$ 1396 \mathrm{~b}$ (a) (2000); see also id. $\$ 1396 \mathrm{~d}(\mathrm{~b})$ (2000) (setting forth the formula for payment to the states and the federal medical assistance percentage).

188. See $\S 1396 d(b)$.

189. For a comparison chart of states' funding under the FMAP and multiplier system for Medicaid, see THE HENRY J. KAISER FAMILY FOUND., 50 STATE COMPARISONS, available at http://statehealthfacts.org (last visited Sept. 17, 2007). 
that follows the minimum requirements set by the federal government and provides additional, optional services as the state sees fit. ${ }^{190}$ Medicaid currently covers approximately forty-two million people. ${ }^{191}$

Medicaid is a separate federal spending program from Medicare. Though Congress enacted both programs in 1965 by amending the Social Security Act, each is established by different statutes, has different administrative and enforcement mechanisms, serves a different social and political policy, and suffers from disparate economic and political weaknesses. ${ }^{192}$ Though one federal agency, the Centers for Medicare and Medicaid Services ("CMS"), oversees both programs, CMS has different subdivisions to facilitate administration of each. ${ }^{193}$

By sheer numbers alone, almost a quarter of the population has the potential to be affected by new interpretations of the many statutes that place conditions on federal spending. ${ }^{194}$ Even so, states are the primary focus of this discussion because the clear notice requirement is unique to the conditional spending that states accept and because the Clawback Provision directly affects states rather than beneficiaries. Also, in the Medicaid context, states look like beneficiaries of federal dollars because of the cooperative federalism structure of the program. ${ }^{195}$ It would be unwise to underestimate the amount of power Congress wields over the healthcare industry by virtue of its ability to place conditions on spending. ${ }^{196}$

190. See $\$ 1396$.

191. See THE KaISER COMMISSION ON MEDiCAID AND THE Uninsured, MEDICAID ENROLLMENT IN 50 STATES 3, 5 (2007), available at http://www.kff.org/medicaid/upload/ 7606_02.pdf.

192. See Sara Rosenbaum, Medicaid at Forty: Revisiting Structure and Meaning in a PostDeficit Reduction Act Era, 9 J. HealTH CARE L. \& POL'Y 5, 10 (2006). Professor Rosenbaum's article provides a pithy yet thorough primer on Medicaid, its history, structure, and future.

193. See Centers for Medicare and Medicaid, CMS Leadership Overview, http://www.cms.hhs.gov/CMSLeadership/01_Overview.asp (last visited Sept. 17, 2007).

194. Large numbers of the most vulnerable Americans may be affected by changes in jurisprudence on conditioned spending. For a discussion of the import and impact of Medicaid and the populations affected by it, see Rosenbaum, supra note 192, at 6 (noting, for example, that Medicaid covers a quarter of all children and a third of all births in the United States).

195. This structure is often called "cooperative federalism." See, e.g., Wis. Dep't of Health and Family Servs. v. Blumer, 534 U.S. 473, 495 (2002) (citing Harris v. McRae, 448 U.S. 297, $308(1980)$ ).

196. See Thomas Wm. Mayo, The First Fifty Years: Health Law's Greatest Hit, 50 SYRACUSE L. REV. 1261, 1265 (2000) (describing the impact of Medicare on the healthcare industry in pure dollars). Additional discussion involving impact on individuals and healthcare providers is certainly warranted and will be addressed at a later time. For example, Title VI of the Civil Rights Act of 1964 , which was enacted by virtue of Spending Clause power, was intended to end discrimination in all programs that accept federal funding, which includes Medicare and Medicaid and thus reaches almost all healthcare providers. See Sara Rosenbaum \& Joel Teitelbaum, Civil Rights Enforcement in the Modern Healthcare System: Reinvigorating the 
In addition to the Medicare and Medicaid programs, a number of significant federal statutes exist that are also conditions on federal spending programs. For example, the Health Insurance Portability and Accountability Act ("HIPAA"), ${ }^{197}$ the Emergency Medical Treatment and Active Labor Act ("EMTALA"), ${ }^{198}$ and the Public Health Service Act 340B Drug Discount Program all create conditions that are tied to acceptance of or participation in Medicare and/or Medicaid and have palpable effects on the healthcare providers in those programs. ${ }^{199}$ These statutes affect Medicare beneficiaries and Medicaid enrollees by various means, including protecting their medical records, ensuring access to emergency medical treatment (which is not limited to beneficiaries of government healthcare programs), and facilitating lower drug prices. Though statutes such as EMTALA and HIPAA aim to protect beneficiaries, they also have an impact on healthcare providers who participate in Medicare and Medicaid.

\section{B. The Medicare Clawback Provision}

As noted briefly above, Medicare contains three separate Parts, which in Medicare parlance means three benefits. ${ }^{200}$ Medicare Part A, known as Hospital Insurance ("HI"), covers institutional care for Medicare beneficiaries. ${ }^{201}$ Medicare Part B, or Supplemental Medical Insurance ("SMI"), covers physicians' services and other items and services that are

Role of the Federal Government in the Aftermath of Alexander v. Sandoval, 3 YALE J. HEALTH POL'Y L. \& ETHICS 215, 217 (2003) (urging the federal government to take action after the Supreme Court ruled that no private right of action exists under Title VI, which makes it very difficult to prove discrimination in providing care to the Medicare and Medicaid populations).

197. The HIPAA public law created a host of fraud and abuse enforcement-strengthening statutes, which are directly related to spending federal Medicare and Medicaid dollars, though one could also classify HIPAA as a Commerce Clause act by virtue of its regulation of the portability of health insurance and the electronic medical record standards that were part of the "Administrative Simplification" provisions. See 42 U.S.C. $\$ \S 1320 \mathrm{~d}$ to $1320 \mathrm{~d}-8$ (2000) (administrative simplification); 42 U.S.C.A. $\$ \S 300 \mathrm{gg}$ to $300 \mathrm{gg}-92$ (West 2003) (health insurance portability standards and some general health insurance regulations); see also Outterson, supra note 178, at 520-21 (describing HIPAA as Commerce Clause legislation).

198. See 42 U.S.C.A. § $1395 \mathrm{dd}$ (West 2003).

199. The 340B Program requires pharmaceutical manufacturers to calculate " $340 \mathrm{~B}$ ceiling prices" using a specified formula; pharmaceutical companies must sell their products at or below the 340B price to continue to receive reimbursement from the Health Resources and Services Administration, which facilitates special programs for certain federal grantees, federally qualified health centers, and disproportionate share hospitals. See U.S. Dep't of Health and Human Services Health Resources and Servs. Admin., Pharmacy Affairs and 340B Drug Pricing Program, http://www.hrsa.gov/opa/introduction.htm (last visited Sept. 17, 2007); see also Veterans Health Care Act of $1992 \S \S 601-03,38$ U.S.C. $\$ 8126$ (2000) (expanding and improving veterans' healthcare benefits to include certain pharmaceutical benefits and limitations on payment for the pharmaceuticals).

200. A fourth programmatic element exists, but it is an amalgamation of the other three Parts, not a benefit.

201. See 42 U.S.C.A. §§ 1395c to $1395 i-5$ (West 2003 \& Supp. 2007). 
professional rather than institutional in nature. ${ }^{202}$ Medicare Part D creates a stand-alone drug benefit for which Medicare beneficiaries may opt-in. ${ }^{203}$ Medicare beneficiaries may use the traditional Medicare structure and access Parts A, B, and D as separate benefits, or they can choose Medicare "Part C," a conglomeration of all three benefits that is facilitated through private managed care entities that are paid subsidies to be in the Medicare market. ${ }^{204}$

Some Medicare beneficiaries, labeled "dual eligibles," are poor enough to qualify for Medicaid in addition to Medicare. ${ }^{205}$ Dual eligibles historically have received drug coverage through Medicaid, which meant that states chose to bear the cost of drugs for the poorest Medicare beneficiaries, who otherwise would not have had drug coverage. ${ }^{206}$ Pharmaceuticals are an optional benefit under the traditional Medicaid structure, but every state has chosen to provide some drug coverage to Medicaid beneficiaries. ${ }^{207}$ Even though Medicare has not covered the cost of outpatient drugs for its beneficiaries since its inception (until the MMA was enacted in 2003), Medicaid long has paid for drugs for some of the poorest, oldest, and (in healthcare matters) costliest members of the population.

Covering the cost of poor senior citizens' drugs has been expensive for states. ${ }^{208}$ Medicaid programs are always under pressure to keep costs down, and rising drug costs have been recognized as a major source of increasing expenses. ${ }^{209}$ Year after year, studies show that senior citizens, in

202. See id. $\$ \S 1395 \mathrm{j}$ to $1395 \mathrm{w}-4$.

203. See id. $\$ \S 1395 w-101$ to 1395 w-152 (West Supp. 2007).

204. See id. $\S \S 1395 w-21$ to 1395 w-29 (West 2003 \& Supp. 2007).

205. See id. $\S 1396 \mathrm{a}(\mathrm{a})(10)(\mathrm{A})(\mathrm{i})(\mathrm{I})$ (West 2003).

206. See BRIAN BRUEN \& JOHN HOLAHAN, KAISER FAMILy Found., SHIFTING THE COST OF DUAL EligiBLES: IMPLICATIONS FOR STATES AND THE FEDERAL GOVERNMENT 1-8 (2003), available at http://www.kff.org/medicaid/upload/Shifting-the-Cost-of-Dual-EligiblesImplications-for-States-and-the-Federal-Government-Issue-Paper.pdf.

207. See BRIAN BRUEN \& JOHN HOLAHAN, KaISER FAMILy Found., The MEdiCAid DRUG BENEFIT: HIGHLIGHTS FROM THE KCMU 2003 SURVEY OF STATES 1 (2003), available at http://www.kff.org/medicaid/upload/The-Medicaid-Drug-Benefit-Highlights-From-the-KCMU2003-Survey-of-States.pdf.

208. In 2003, the states spent an estimated $\$ 15.2$ billion covering prescription drugs for dual

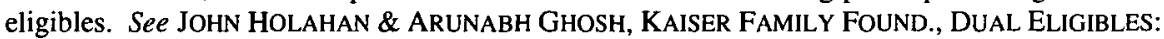
MEDICAID ENROLLMENT AND SPENDING FOR MEDICARE BENEFICIARIES IN 20036 (2005), available at http://www.kff.org/medicaid/upload/7346\%20Dual\%20Eligibles_Enrollment\%20and \%20Spending_Beneficiaries_Final_revised\%207_28.pdf.

209. See Medicaid Program; Prescription Drugs; Proposed Rules, 71 Fed. Reg. 77174, 77174-75 (Dec. 22, 2006) (to be codified at 42 C.F.R. pt. 447); see also Robert Pear, U.S. Is Proposing To Cut Medicaid's Drug Payments, N.Y. TIMES, Dec. 18, 2006, at A16 (describing a plan to pay pharmacies less for Medicaid prescriptions by revamping the controversial formula for average manufacturer price and the requirement for brand name drugs to be swapped for generics whenever possible, as mandated by the Deficit Reduction Act of 2005). 
addition to the permanently disabled, account for between one-third and one-half of Medicaid costs, even though they are only a fifth of the Medicaid enrollee population. ${ }^{210}$ Even when the overall rate of health expenditures started to slow down in the early twenty-first century, the rate of increase for the cost of pharmaceuticals continued to increase dramatically. ${ }^{211}$ Accordingly, each state has different Medicaid ingredients designed to help limit the burden of paying for drugs; for example, some states limit their formularies to generic drugs, some states have increased cost sharing depending on the classification of drug, and some states place limits on the number of prescriptions that Medicaid will pay for. ${ }^{212}$ States welcomed Congress's promise to move the fiscal responsibility for dual eligibles' drugs to Medicare Part D. ${ }^{213}$

210. For instance, in 2003, dual eligibles accounted for forty-two percent of Medicaid spending but were only sixteen percent of the Medicaid population. See KAISER COMM'N ON MEDiCAID AND THE UNINSURED, DuAL Eligibles: MEDICAID's ROLE IN FILLING THE GAPS 1 (2004), available at http://www.kff.org/medicaid/upload/Dual-Eligibles-Medicaid-s-Role-inFilling-Medicare-s-Gaps.pdf; see also KAISER COMM'N ON MEDICAID AND THE UNINSURED, DUAL Eligibles: MEDICAID's ROLE FOR LOW-INCOME MEDICARE BENEFICIARIES 2 (2006), available at http://www.kff.org/medicaid/upload/Dual-Eligibles-Medicaid-s-Role-for-LowIncome-Medicare-Beneficiaries-Feb-2006.pdf (noting that dual eligibles comprise forty percent of total Medicaid spending); KAISER COMM'N ON MEDICAID AND THE UNINSURED, DUAL. ELIGIBLES: MEDICAID'S ROLE FOR LOW-INCOME MEDICARE BENEFICIARIES 1 (2005), available at http://www.kff.org/medicaid/upload/4091-04\%20Final(v2).pdf (noting that dual eligibles comprise forty percent of total Medicaid spending); KAISER COMM'N ON MEDICAID AND THE UNINSURED, DUAL ELIGIBLES: MEDICAID'S ROLE FOR LOW-INCOME MEDICARE BENEFICIARIES 1 (2004), available at http://www.kff.org/medicaid/upload/Dual-Eligibles-Medicaid-s-Role-forLow-Income-Medicare-Beneficiaries-Fact-Sheet-2.pdf (noting that dual eligibles comprise fortytwo percent of total Medicaid spending); KAISER COMM'N ON MEDICAID AND THE UNINSURED, DUAL Eligibles: MEdiCAID'S ROLE FOR LOW-INCOME MEDICARE BENEFICIARIES 1 (2003), available at http://www.kff.org/medicaid/upload/Dual-Enrollees-Medicaid-s-Role-for-LowIncome-Medicare-Beneficiaries-Fact-Sheet.pdf (noting that dual eligibles comprise thirty-five percent of total Medicaid spending).

211. See allison Woo, Usha Ranji, Janet lundy \& Fannie Chen, The Henry J. Kaiser FAMILY FOUND., PRESCRIPTION DRUG COSTS, available at http://www.kaiseredu.org/topics_im. asp?id=352\&parentID=68\&imID=1 (last visited Sept. 15, 2007) (providing statistical information regarding rising drug expenses, such as the six percent growth in prescription drug expenses from 2004 to 2005).

212. See JefFrey S. Crowley, Deb ashner \& Linda Elam, The Henry J. Kaiser Family Found., STATE MEdiCaId OUTPatient PRESCRIPTION DRug Policies: Findings FROM A NATIONAL SURVEY, 2005 UPDATE, at v-xi (2005), available at http://www.kff.org/ medicaid/upload/State-Medicaid-Outpatient-Prescription-Drug-Policies-Findings-from-a-

National-Survey-2005-Update-report-executive-summary.pdf (finding that in 2005, nearly all states enacted dispensing limits and required the use of generics, and four out of five states required copayments for prescription drugs).

213. The National Governors Association has formulated a policy that calls for shifting all dual eligibles to Medicare and for a system for long-term care payment that goes beyond just Medicaid. See Nat'l Governors Ass'n, Medicaid Reform Principles Policy, HHS-27 (adopted 2003, revised in 2005 and 2007), available at http://www.nga.org (follow "Policy Positions" hyperlink under "Federal Relations"; then follow "HHS-27 Medicaid Reform Principles" hyperlink). 
The switch from Medicaid to Medicare did not occur quite as the states anticipated, however, and many were surprised to learn that Congress shifted only the administrative aspect of the drug benefit to Medicare; states continue to bear the cost of dual eligibles' drugs, as mandated by the Clawback Provision. ${ }^{214}$ To understand the peculiarity of the Clawback Provision, it is important to differentiate Medicaid from Medicare. As was just discussed, states have covered drug costs of poor seniors since the inception of the Medicaid program; however, this payment system exists because senior citizens are a qualifying category of "deserving poor" in the Medicaid statute. ${ }^{215}$ This aspect of the Medicare and Medicaid programs is odd. All seniors should have been covered by Medicare with, for instance, special provisions for waiver of cost sharing, rather than Medicaid including seniors as a category of "deserving poor."216 The dual eligible system is also strange because Medicare is a permanent method of insurance, whereas Medicaid is intended as a stopgap for those who are poor but (the government believes) will not always be so. ${ }^{217}$ The poor elderly are unlikely to change their wealth status, which seems contrary to the welfare theory of Medicaid (as opposed to the social insurance theory

214. The word "clawback" appears to have entered American legal commentary by way of British political discourse, which used "clawback" to describe a provision in the British Protection of International Trading Interests Act of 1980. See Laker Airways Ltd. v. Pan Am. World Airways, 559 F. Supp. 1124, 1137 (D.D.C. 1983); Joseph E. Neuhaus, Power To Reverse Foreign Judgments: The British Clawback Statute Under International Law, 81 COLUM. L. REV. 1097, 1097 n.2 (1981). That law enabled British companies that had lost antitrust cases in the United States and that had been subject to treble damages to sue the prevailing plaintiffs in British court to recover, or "clawback," the awarded damages. See Michael J. Danaher, Anti-Antitrust Law: The Clawback and Other Features of the United Kingdom Protection of Trading Interests Act, 12 LAW \& POL'Y INT'L Bus. 947, 958 (1980). The use of the term in the context of the Clawback Provision of the MMA mirrors this original use; states received a significant economic benefit when Medicare Part D took over dual eligibles, but the federal government is entitled to "clawback" that benefit under the MMA. The Tax Court has used the term in a similar context to describe recapture of deferred taxes under 1975 British tax law. See Am. Air Filter Co. v. Comm'r, 81 T.C. 709, 715 (1983). In the 1990's, "clawback" was employed in commentary on American tax law. See George K. Yin, Summary of EITC Conference Proceedings, 11 AM. J. TAX POL'Y 299, 310 (1994). American scholars have also used "clawback" to describe provisions in contract, bankruptcy, and partnership law.

215. See 42 U.S.C.A. § 1396a(m) (West 2003); id. § 1396d(a)(iii) (describing people sixtyfive years of age or older as a category of eligibility for Medicaid so long as the elderly person is not making more than $100 \%$ of the federally determined poverty level).

216. See THE HENRY J. KAISER FAMILY FOUND., MEDICARE BENEFICIARIES: A POPULATION AT RISK (1999), available at http://www.kff.org/medicare/1459-risk.cfm (describing the dire status of many Medicare beneficiaries, including their poor health status, low incomes (a broader definition than federal poverty status), and the particularly precarious positions of women and minorities).

217. See Robert STEVEns \& Rosemary Stevens, Welfare Medicine IN AMERICA 42-53 (1974) (describing the political and historical convergences that resulted in the current format of Medicare and Medicaid and noting the differing philosophical approaches to each program). 
of Medicare). ${ }^{218}$ Nevertheless, dual eligibles are part of the system, and the Medicaid enabling statutes recognize the need to pay Medicare premiums, deductibles, and copayments on behalf of elderly Medicaid beneficiaries in the process of paying for certain medical care and services. ${ }^{219}$ Formulae are set forth for such payments. ${ }^{220}$ Just as it would pay any healthcare provider, Medicaid in certain situations pays Medicare cost-sharing obligations on behalf of elderly poor. ${ }^{221}$

The Clawback Provision requires that states relinquish control over pharmaceuticals for dual eligibles to Medicare. Drugs are quite expensive, and the shifting of responsibility to Medicare would sound beneficial for states, except that they are required to, for the foreseeable future, pay the federal government the cost of dual eligibles' pharmaceuticals based on an algorithm founded in states' Medicaid drug expenses from 2003. ${ }^{222}$ Generally, this calculation requires states to pay the federal government the cost of covering drugs for the fully eligible dual eligible population in the state in the year 2003, taking into account the extant number of full-benefit dual eligibles in the year the payment is being made and a growth factorall of which is reduced by a small percentage according to the statute. ${ }^{223}$

218. This discrepancy is tied to old ideas of "medical indigence." See id. at xvi (describing medical indigence as a concept that limited the possible forms of Medicaid and Medicare).

219. See $\$ 1396 \mathrm{~d}(\mathrm{p})$.

220. See id.

221. This description is simplified, as a variety of paths exist for Medicare beneficiaries to receive Medicaid benefits. For a description of the Medicare/Medicaid interplay for dual eligibles, see THE HenRy J. KaISER FAMILy FOUND., KaISER COMMISSION ON MEDICAID FACTS, DuAl Eligibles: MEDICAID's ROLE FOR LOW-INCOME MEDICARE BENEFICIARIES 1-2 (2006), available at http://kff.org/medicaid/upload/Dual-Eligibles-Medicaid-s-Role-for-LowIncome-Medicare-Beneficiaries-Feb-2006.pdf.

222. See 42 U.S.C.A § 1396u-5(c) (West Supp. 2007).

223. See $\S 1396 u-5$. The statutory language, in pertinent part, is as follows:

(a) Requirements relating to medicare prescription drug low-income subsidies and medicare transitional prescription drug assistance .... :

As a condition of its State plan under this subchapter ... and receipt of any Federal financial assistance ... subject to subsection (e) of this section, a State shall do the following: ...

(c) Federal assumption of medicaid prescription drug costs for dually eligible individuals....

Each of the 50 States and the District of Columbia for each month beginning with January 2006 shall provide for payment under this subsection to the Secretary of the product of -

(i) the amount computed under paragraph (2)(A) for the State and month;

(ii) the total number of full-benefit dual eligible individuals ... for such State and month; and

(iii) the factor for the month specified in paragraph (5) ...

Payment under subparagraph (A) shall be made in a manner specified by the Secretary that is similar to the manner in which State payments are made under an agreement entered into under section $1395 \mathrm{v}$ of this title, except that all such payments shall be deposited into the Medicare Prescription Drug Account in the 
Though the Clawback is called "phased-down" in the statute, the least states will pay under the current scheme is seventy-five percent of the drug costs from 2003. ${ }^{224}$ If states do not pay the federal government the "clawback" amount, they stand to lose all of their federal Medicaid funding, though the first step is for the federal government to charge interest, withhold the Medicaid dollars from states' accounts, and reallocate the Medicaid dollars to the Medicare Prescription Drug Account. ${ }^{225}$

The Clawback Provision does not fit neatly within the existing dual eligible schema, so its shady genesis (it was created primarily behind closed doors ${ }^{226}$ ) is worthy of brief description. ${ }^{227}$ For instance, the House

Federal Supplementary Medical Insurance Trust Fund. ... If a State fails to pay to the Secretary an amount required under subparagraph (A), interest shall accrue .... The amount so owed and applicable interest shall be immediately offset against amounts otherwise payable to the State under section 1396b(a) of this title subject to subsection (e) of this title ....

The amount computed under this paragraph for a State described in paragraph (1) and for a month in a year is equal to-

(i) $1 / 12$ of the product of -

(I) the base year State medicaid per capita expenditures for covered part D drugs for full-benefit dual eligible individuals (as computed under paragraph (3)); and (II) a proportion equal to 100 percent minus the Federal medical assistance percentage ...; and

(ii) increased for each year (beginning with 2004 up to and including the year involved) by the applicable growth factor specified in paragraph (4) for that year....

The Secretary shall notify each State ... not later than October 15 before the beginning of each year (beginning with 2006) of the amount computed under subparagraph (A) for the State for that year.

Id.

224. See $\S 1396 \mathrm{u}-5(\mathrm{c})(5)$.

225. See $\$ 1396 \mathrm{u}-5(\mathrm{c})(1)(\mathrm{B})-(\mathrm{C})$. The statute refers to the under/overpayment process set forth at 42 U.S.C.A. $\$ 1396 \mathrm{~b}$ (d), but that process does not directly correlate because the funds are not transferred directly to Medicare accounts. See $\S 1396 \mathrm{u}-5(\mathrm{c})(1)(\mathrm{C})$. Also, although the Clawback Provision itself only threatens offsets if states fail to comply, that is not the only possible penalty. All states are subject to a blanket penalty provision that gives the Secretary of the Department of Health and Human Services the power to withhold all Medicaid payments for failure to comply with Medicaid statutes and regulations. See id. §1396c (West 2003).

226. Many Democratic lawmakers complained of exclusion from the secret committee sessions from which the Clawback Provision emerged, which at the time were consistently reported to be closed-door, invitation-only negotiations. See Robert Pear \& Carl Hulse, Rewriting Top Legislation Is an Invitation-Only Party, N.Y. TIMES, Oct. 26, 2003, at Al (reporting that although seventeen members of Congress were appointed to the committee that had the undeniably difficult task of reconciling the House and Senate versions of the Medicare prescription drug bill, only twelve were permitted to participate in the committee's sessions and most Democrats, including the Senate minority leader Tom Daschle, were "excluded"); see also Democrats Demand Inclusion in Medicare Rx Drug Conference, INSIDE CMS, Oct. 23, 2003, at 8 (reporting that Democratic conferees sent a public letter to Representatives Bill Thomas and Billy Tauzin and Senator Chuck Grassley, decrying their exclusion from the Medicare drug bill negotiations, and noting the two Democrats who were permitted to participate were Senators Max Baucus (Mont.) and John Breaux (La.)). 
included a phase-in period for moving dual eligibles from Medicaid to Medicare and a calculation for paying for dual eligibles' drugs in its bill, but it did not appear to require states to pay the federal government for the phase-in. ${ }^{228}$ The Senate did not address federal assumption of dual eligibles in its bill. ${ }^{229}$ It was notoriously difficult for the participants in the secret conference committee to complete the crafting of the Medicare drug bill, and the public may never fully understand the machinations that occurred. $^{230}$ Thus, the Clawback Provision is some combination of the House and Senate bills; yet, it has a completely different conception of responsibility for the dual eligible population, requiring states to pay for what has become a federal program benefit. Perhaps the most puzzling aspect of the Clawback Provision is that Congress had other, less questionable options. For instance, Congress could have paid less to states-based upon the states' reduced costs from no longer covering seniors' pharmaceuticals - and reallocated the saved dollars to Medicare Part D. Relatively simple amendments to the FMAP to incorporate such a formula would not have added significantly to the complexity of the MMA.

\section{The States' Challenge to the Clawback Provision}

At least three characterizations of the Clawback Provision are possible: it could be a tax on the states, a kind of condition on federal spending, or Congressional commandeering of the states. Several states responded predictably to this confusing, mandatory, and potentially expensive plan: they sued.

227. The bills that created the MMA had many strange elements; for instance, a new subagency was proposed to administer Medicare Advantage and Part D, which would have been the "Center for Medicare Choices." See House of Representatives, Conference Report on H.R. 1, Medicare Prescription Drug and Modernization Act of 2003, 149 CONG. REC. H1 1877, Hl 1985 (daily ed. Nov. 20, 2003). The changing names of the legislation are interesting as well: "Medicare Prescription Drug and Modernization Act of 2003" in the House and "Prescription Drug and Medicare Improvement Act of 2003" in the Senate (ultimately combined to include both improvement and modernization for Medicare). Id.; see also 149 CONG. REC. 16604 (2003).

228. See Medicare Prescription Drug and Modernization Act of 2003, H.R. 1, 108th Cong. $\S 111$ (Engrossed as Agreed to or Passed by House, 2003), 149 CONG. REC. 16297 (2003). This language closely resembles language proposed in the House in 2000 for the Medicare RX 2000 Act. See H.R. REP. No. 106-703(I), at 19-21 (2000).

229. Senator Rockefeller introduced an amendment to cover dual eligibles that Senator Grassley effectively opposed. See Prescription Drug and Medicare Improvement Act of 2003, H.R. 1 108th Cong. $\$ 104$ (Engrossed Amendment as Agreed to by the Senate), 149 CONG. REC. 16972-73 (2003); see also 149 CONG. REC. 16639-40 (2003).

230. See Jill Zuckman, GOP's Go-To Leader on Capitol Hill Hastert Resolves Conflicts on Bills Such as Medicare Drug Plan, CHI. TRIB., Nov. 21, 2003, $\S 1$, at 8 (reporting that the allRepublican committee, "even though they'd excluded most Democrats from the process," could not reconcile the drug bill without the intervention of Speaker Hastert). 
The Supreme Court denied original jurisdiction in Texas v. Leavitt, but the states appear ready to proceed in their respective district courts. ${ }^{231}$ The Supreme Court action was filed by Kentucky, New Jersey, Texas, Maine, and Missouri (the "Petitioners"), and Arizona, Alaska, Connecticut, Kansas, Mississippi, New Hampshire, Ohio, Oklahoma, South Carolina, and Vermont filed as amici curiae. ${ }^{232}$ The causes of action included a claim of an unconstitutional tax against the states, unconstitutional commandeering by requiring the states to allocate state taxpayer dollars for the Medicare program, and violation of the Guarantee Clause. ${ }^{233}$ The Guarantee Clause issue probably will be deemed a nonjusticiable political question and thus will be unsuccessful, even though some scholars have noted that New York $v$. United States may have opened the door to future actions under the Guarantee Clause. ${ }^{234}$ Interesting too are the possibilities presented by the impermissible tax claim and the commandeering claim. The thrust of the impermissible tax claim was that the MMA created a new and unique tax on the states by forcing them to directly fund a federal program, a violation of principles last enunciated by the Court in $1946 . .^{235}$

231. See Texas v. Leavitt, 548 U.S. 126 S. Ct. 2915 (2006) (mem.) (denying leave to file complaint and denying preliminary injunctive relief).

232. Brief of the States of Arizona, Alaska, Connecticut, Kansas, Mississippi, New Hampshire, Ohio, Oklahoma, South Carolina, and Vermont as Amici Curiae in Support of Plaintiffs, Leavitt, 548 U.S. 126 S. Ct. 2915, 2915 (2006) (No. 05-135), available at http://www.oag.state.tx.us/newspubs/releases/2006/030306medicare_sweeney.pdf.

233. See Brief for Motion for Leave to File Bill of Complaint, Supporting Brief, and Bill of Complaint at 3-4, Leavitt, 548 U.S. 126 S. Ct. 2915, 2915 (2006) (No. 05-135), available at http://www.oag.state.tx.us/newspubs/releases/2006/030306medicare_sweeney.pdf.

234. See U.S. CoNST. art. IV, § 4 ("The United States shall guarantee to every State in this Union a Republican Form of Government ...."). This is also called the Republican Form of Government Clause. Under either name, the clause is generally deemed nonjusticiable, at least with regard to individuals, due to the political question doctrine. See, e.g., Baker v. Carr, 369 U.S. 186, 209-30 (1962) (discussing the nonjusticiable nature of disputes that arise under the Guarantee Clause). Regarding protection of the states, some believe that room exists to protect the states from improper federal government intrusion. See, e.g., TRIBE, supra note 1, at 910-11. Professor Tribe noted: "[I]t need not follow from the unavailability of the Guarantee Clause as a textual source of protection for individuals that the clause confers no judicially enforceable rights upon states as states. It is, after all, 'to every state' that the promise of the Guarantee Clause is addressed." Id. Professor Tribe drew in part on dicta in New York v. United States, 505 U.S. 144 (1992), that the justiciability of the Guarantee Clause was not a foregone conclusion. TRIBE, supra note 1 , at 911 . The Court never reached the merits of that argument, having already revitalized the Tenth Amendment. Id.

235. See New York v. United States, 326 U.S. 572, 575-84 (1946). The analysis often begins with McCulloch v. Maryland, 17 U.S. (4 Wheat.) 316 (1819), and the legendary statement by Chief Justice Marshall that the "power to tax involves the power to destroy." Id. at 431 . The Court in South Carolina v. Baker, 485 U.S. 505 (1988), purportedly clarified this statement by noting that the federal government enjoys greater tax immunity than the states do, but the Court declined to resolve how the balance works. McCulloch, 17 U.S. (4 Wheat.) at 523 n.14. Note that South Carolina v. Baker predates New York v. United States, so it contains conclusions regarding the Tenth Amendment that are no longer correct statements of the law. 
The Petitioners thus asked the Supreme Court to illuminate the underdeveloped doctrine of inter-governmental tax immunity. ${ }^{236}$ The commandeering claim is founded in the principles that derive from the 1992 case of New York $v$. United States, ${ }^{237}$ which stated that the federal government cannot force the states to legislate in lieu of directly commanding the states to participate in a federal scheme. More specifically, the Petitioners alleged they will be forced to allocate taxpayer dollars to pay the federal government for a federal program, which essentially creates forced legislative action that would implicate the Tenth Amendment. ${ }^{238}$

The Petitioners also argued that the Clawback Provision is not a condition on spending at all, stating that Congress knows how to compose conditions on federal spending and that the Clawback Provision is not worded like a condition on spending such as, for example, the requirement to create drinking age laws for federal highway funding. ${ }^{239}$ They urged the Court to recognize the difference between commanding states to pass legislation to receive funds and commanding states to pay money to fund a federal program (Medicare) to receive continued federal funding for a different program (Medicaid), with a threat of offset and a penalty of interest for the states' program (Medicaid) if the funds are not paid to the federal program (Medicare). In short, the Petitioners insisted that a requirement to fund Medicare cannot be characterized as a condition on receipt of federal Medicaid dollars, but they buried in a footnote ${ }^{240}$ the important point that the Clawback Provision not only fails to fit the known world of Spending Clause jurisprudence, but also affects the structure of Medicaid, which traditionally has allowed states to choose whether to provide the statutorily optional pharmaceutical benefit. ${ }^{241}$ States must fund the Medicare program in its provision of the drug benefit to the elderly or face total loss of Medicaid funds, removing from states' control the option to provide a drug benefit. ${ }^{242}$

236. Brief for Motion for Leave to File Bill of Complaint, Supporting Brief, and Bill of Complaint, supra note 233, at 5-14.

237. 505 U.S. 144 (1992).

238. Id. at $16-19$.

239. Id. at 14-16.

240. Id. at 15 n.9.

241. See 42 U.S.C.A. § 1396d(a) (West Supp. 2007) (delineating "optional" benefits that can be provided by states, as opposed to mandatory benefits that must be provided by states to all Medicaid enrollees).

242. Brief for Motion for Leave to File Bill of Complaint, Supporting Brief, and Bill of Complaint, supra note 233, at 16. 
If the attorneys general who filed the original action pursue the case in their respective venues, ${ }^{243}$ it may behoove them to consider a stronger Spending Clause analysis and argument. Though the Petitioners analyzed the Clawback Provision under Dole, they did not capture the essence of the clear notice requirement, especially in light of Arlington. ${ }^{244}$

\section{Analysis of the Clawback in Light of Arlington}

The Clawback Provision only vaguely resembles a condition on spending. Typically, when states are required to spend state government funds to create programs that are cofounded and funded by the federal government within the structure called cooperative federalism, the funds are spent on a program that the state controls according to federal guidelines. ${ }^{245}$ If the state does not like the federal government's guidelines, it need not accept federal money and thus either self-funds or does not institute the program. In part, this is the point of the clear notice rule as articulated by Justice Alito-a state cannot knowingly accept the conditions of federal funds if the conditions are not clearly set forth for the state to accept or reject. ${ }^{246}$

Under the Clawback Provision, states must give state taxpayer dollars to Medicare, a federal program, to fund a new feature of that federal program, not to support states' Medicaid programs. ${ }^{247}$ The language of the

243. See Texas v. Leavitt, 548 U.S. , 126 S. Ct. 2915 (2006) (mem.).

244. See Brief for Motion for Leave to File Bill of Complaint, Supporting Brief, and Bill of Complaint, supra note 233, at 15 n.10.

245. See Robert F. Rich, Cinthia L. Deye \& Elizabeth Mazur, The State Children's Health Insurance Program: An Administrative Experiment in Federalism, 2004 U. ILL. L. REV. 107, 109.

246. See Arlington Cent. Sch. Dist. Bd. of Educ. v. Murphy, 548 U.S. _, 126 S. Ct. 2455 , 2459 (2006).

247. It is difficult to imagine how Congress could have considered this a legitimate condition on spending. Because the negotiations leading to the creation of the Clawback Provision occurred in closed conferences, see supra note 226 and accompanying text, insight is not provided in the Congressional Record. The Brief for the Secretary of Health and Human Services in Opposition to the Petitioners is helpful, though. See Brief for the Secretary of Health and Human Services in Opposition, Leavitt, 548 U.S. 126 S. Ct. 2915 (2006) (No. 05-135). The Secretary calls the Clawback Provision "merely an accounting mechanism" that applies "only to States that choose to participate in the Medicaid program." Id. at 2, 17. (Of course, every state now relies heavily on federal Medicaid dollars.) The Secretary relied heavily on the theory that the Clawback eventually would save the states money by virtue of the federal government paying for Part D drug expenses for dual eligibles. See id. at 2, 7, 21. Studies have shown that the Clawback will cost the states between $\$ 6.6$ billion and $\$ 7.3$ billion for 2006. See, e.g., THE HenRy J. Kaiser Family Found., AN UPDate on the Clawback: Revised Health Spending Data Change State Financial Obligations for the New Medicare DRUG BENEFIT 1 fig.1 (2006), available at http:/www.kff.org/medicaid/upload/7481.pdf. In the Brief in Opposition to the Petition for Original Jurisdiction, the Secretary also supported the legality of the Clawback by noting that non-complying states suffer only an offset with interest; 
law alone renders it suspect as conditional spending. ${ }^{248}$ For instance, the statutory section is entitled "Special provisions relating to Medicare prescription drug benefit." 249 "While the first two subsections read like traditional conditions on spending-state Medicaid administrators are directed to provide information and, as they do for other costs related to Medicaid, will receive federal dollars for their hassle much as they do, by statute, for other costs related to Medicaid ${ }^{250}$ - the Clawback subsection begins with the title "Federal assumption of Medicaid prescription drug costs for dually eligible individuals" and then describes how states will provide funds to the federal government to support Medicare's assumption of drug costs. ${ }^{251}$ This language does not signal conditions on spending as they have been understood.

Despite these unusual features, Medicaid and Medicare are federal spending programs and the Clawback Provision is a condition on states' acceptance of Medicaid funding. Thus, this paper analyzes the Clawback Provision by application of the Dole test as modified by Arlington. Assuming that the conditional spending at issue is the acceptance of federal funds for state Medicaid programs, the first Dole element is not problematic, as Medicaid can fairly be considered an act of federal spending that is in pursuit of the general welfare. Additionally, the first Dole factor has yet to be enforced by federal courts.

The Pennhurst/Dole second category, requiring that conditions on spending be unambiguous and modified by Arlington's clear notice language, may not provide the guidance for clear statement rules that the Arlington majority anticipated. Justice O'Connor often found that conditions were adequately clear, even when the challenged condition's inference was not clearly part of the statute's language. The Arlington

however, Medicaid has a blanket provision that gives the Secretary power to exclude any state from Medicaid for failure to comply with the Medicaid conditions of participation. See 42 U.S.C. $\S 1396 \mathrm{c}$ (2000); see also Brief for the Secretary of Health and Human Services in Opposition at 3, supra. States have to comply with their own State Plan, and within the State Plan a state might choose to cover drug expenses and thus be held to that promise by CMS. The Clawback eliminates states' ability to remove drug coverage from their State Plans by forcing states to pay the federal government the cost of drugs for dual eligibles, thus rendering the threat of total exclusion still relevant. The Secretary's Brief does not address this problem. It does, however, admit that the Clawback is an "important source of the funding necessary to furnish prescription drugs." See Brief for the Secretary of Health and Human Services in Opposition, supra, at 27-28.

248. As the Petitioners noted, the Clawback Provision is like a tax on the states, rather than a condition of spending. Brief for Motion for Leave to File Bill of Complaint, Supporting Brief, and Bill of Complaint, supra note 233, at 16.

249. 42 U.S.C.A. § 1396u-5 (West Supp. 2007).

250. $\$ 1396 \mathrm{u}-5(\mathrm{a})-(\mathrm{b})$ (providing reimbursement for administrative work related to the Clawback); 42 U.S.C. $\$ 1396 \mathrm{~b}$ (2000) (providing reimbursement to states for general administrative costs related to Medicaid).

251. §1396u-5(c). 
clear notice language means that not all statutory language will pass the second Dole element, but we do not yet know how clear "clear notice" must be. For instance, Medicare and Medicaid both contain innumerable conditions in constantly changing statutory and regulatory schemes; the new clear notice requirement raises the question whether that set of conditions could be considered "clear" from the perspective of states and of healthcare providers. Perhaps more importantly, Arlington does not address the line that is crossed when new conditions are continuously added to a long-standing federal program, which implicates the issue of coercion in addition to knowing acceptance of conditions on spending.

However, for purposes of this immediate analysis, the question is whether the statutory language of the Clawback Provision is clear. No state could have anticipated the Clawback Provision when accepting Medicaid funds in the 1960s and 1970s, a temporal requirement that is implicated by Justice Kennedy's Davis dissent and by Justice Alito's Arlington majority (though, admittedly, this may extend the reach of Arlington a bit far). ${ }^{252}$ The Clawback Provision's algorithm has some clear elements, but the provision is unclear given that states must wait for the Department of Health and Human Services to calculate the clawback each year, which affects the budget process of each state. Also, Justice Alito cautioned Congress to read funding conditions from the perspective of a state, with the warning that states cannot knowingly accept conditions "they are 'unable to ascertain.'" 253 If the Court believed that states would not know they would have to compensate parents for expert fees given the IDEA feeshifting language, then the Court could find the unknowable sum due the federal government under the Clawback Provision similarly unconstitutional. The alternative is that states could forgo all federal Medicaid funds (the position of the Department of Health and Human Services), ${ }^{254}$ an unsatisfactory response given how many citizens rely on Medicaid and how long states have relied on federal spending to provide health insurance and services to the poor. If the states do not accept the Clawback Provision, and they stand to lose all funds, then the fifth Dole element, "compulsion," is implicated as well.

Third, we ask whether the conditions on federal monies are sufficiently related "to the federal interest in particular national projects or

252. Not every state immediately accepted Medicaid funds. See STEVENS \& STEVENS, supra note 217 , at xvi (noting that in 1974 the Medicaid program had been accepted by every state but Arizona).

253. Arlington Cent. Sch. Bd. of Educ. v. Murphy, 548 U.S. , 126 S. Ct. 2455,2459 (2006) (citing Pennhurst State Sch. \& Hosp. v. Halderman, 451 U.S. 1, 17 (1981)).

254. This is the historic response to state complaints regarding spending conditions. See supra Part I.A.3.b. 
programs," otherwise called germaneness. ${ }^{255}$ More directly, the issue is whether federal implementation of the Medicare drug benefit is germane to forcing states to pay part of the expense, which reinforces the question of how a state payment can be a condition of the receipt of funds. The states are not spending for their own Medicaid programs; they are funding the federal Medicare program. It is hard to consider this kind of requirement, which gives the states no choice but to pay the federal government for a program that is separate from the conditional spending, germane to the Medicaid program. Either dual eligibles are covered by Medicare or they are covered by Medicaid; if they are covered by Medicaid, then the states are responsible for optional drug expenses they choose to cover and will receive a match from the federal government. But, if the drug expenses of dual eligibles are covered by Medicare, then the states are no longer in the payment picture (though information may still flow to the federal government, as the states are the gateway to welfare programs for people who are impoverished). Is paying the federal government to fund its own program germane to a state program created pursuant to federal guidelines? The answer must be no, though like the first Dole element, the Court has yet to enforce this requirement. Admittedly, this element is not affected by Arlington, but the Court's willingness to revisit the Spending Clause doctrine may indicate future contemplation of other Dole elements.

Fourth, Dole prohibits violations of other constitutional provisions, which most often applies to conditions that violate individual rights. In this instance, the states, not individuals, are being subjected to potentially unconstitutional conditions, which raises the specter of the Tenth Amendment. The petitioners asserted other arguable constitutional violations not linked to spending, such as the Guarantee Clause. ${ }^{256}$ The likelihood that the Guarantee Clause would be enforced as an unconstitutional condition on the states is low given the Court's reluctance to enforce this Dole limitation for anyone other than individuals. ${ }^{257}$

Under Dole, the Court sought unambiguous conditions on federal spending. After Arlington, unambiguous conditions have morphed into clear notice, a clarification Justice Kennedy and other members of the Court long sought. ${ }^{258}$ "Notice" indicates that advance warning is supplied

255. This factor was key to Justice O'Connor's dissent in South Dakota v. Dole, 483 U.S. 203, 212-14 (1987) (O'Connor, J. dissenting).

256. See generally Luther v. Borden, 48 U.S. (7 How.) 1 (1849) (establishing the nonjusticiability of the Guarantee Clause). But see Colegrove v. Green, 328 U.S. 549, 566-74 (1946) (Black, J., dissenting) (suggesting the Guarantee Clause could be justiciable).

257. See Kathleen M. Sullivan, Unconstitutional Conditions, 102 HARV. L. REV. 1413, 141617 (1989) (noting that the doctrine once was used to protect corporations' economic liberties, but that it now protects individual liberties, though with many inconsistencies).

258. See supra notes 56-57, 60-66, 71-73 and accompanying text. 
to a party (in this instance, the states), and the party then may have a choice in considering whether to participate in the federal program and become subject to its attendant conditions. "Clear" notice indicates not only that the state had advance warning, but also that the warning made plain the terms of accepting the federal money. This would indicate an analytical shift that requires clear statutory language and that, by including a temporal requirement that the states understand the implications of accepting and implementing a federal program with that federal money, could foreclose the constitutionality of notice when the requirement is not made clear originally (when the state accepts funding). If that is the meaning of "clear notice," then the states could not have anticipated or understood that the new price of Medicaid funding would be paying for federal programs through the early part of the twenty-first century.

Pennhurst did not emphasize clear notice language in articulating conditional spending doctrine; as noted above, that language was part of a closing summary of the Court's decision. ${ }^{259}$ Justice Ginsburg valued this distinction, and she made another in Arlington that may be important for understanding the impact on healthcare programs. Justice Ginsburg noted that Pennhurst should not be unmoored from the context of states participating in a federal program when, in that case, the states could not have anticipated a "new [programmatic] obligation for participating" in the federal spending scheme. ${ }^{260}$ Thus, Justice Ginsburg noted the element that should have been emphasized by the petitioners: states could not have ascertained they would be paying the federal government drug costs based

259. Pennhurst State Sch. \& Hosp. v. Halderman, 451 U.S. 1, 25 (1981). The clear notice articulation in Arlington is as follows:

Congress has broad power to set the terms on which it disburses federal money to the States, see, e.g., South Dakota v. Dole, 483 U.S. 203, 206-207, 107 S.Ct. 2793, 97

L.Ed.2d 171 (1987), but when Congress attaches conditions to a State's acceptance of federal funds, the conditions must be set out "unambiguously," see Pennhurst State School and Hospital v. Halderman, 451 U.S. 1, 17, 101 S.Ct. 1531, 67 L.Ed.2d 694 (1981); Rowley, supra, at 204, n.26, 102 S.Ct. 3034. "[L]egislation enacted pursuant to the spending power is much in the nature of a contract," and therefore, to be bound by "federally imposed conditions," recipients of federal funds must accept them "voluntarily and knowingly." Pennhurst, 451 U.S., at 17, 101 S.Ct. 1531. States cannot knowingly accept conditions of which they are "unaware" or which they are "unable to ascertain." Ibid. Thus . . we must view the IDEA from the perspective of a state official who is engaged in the process of deciding whether the State should accept IDEA funds and the obligations that go with those funds. ... In other words, we must ask whether the IDEA furnishes clear notice regarding the liability at issue in this case.

Arlington Cent. Sch. Dist. Bd. of Educ. v. Murphy, 548 U.S. 126 S. Ct. 2455,2459 (2006).

260. Arlington, 548 U.S. at , 126 S. Ct. at 2464 (citing Bell v. New Jersey, 461 U.S. 773, 790 n.17 (1983)). 
on a 2003 algorithm as the price for shifting responsibility for dual eligibles' drug costs.

The states were subject to a late-program switch, which does not appear to comport with the Arlington majority's description of clear notice for conditions or with Justice Ginsburg's concurrence. If the federal government did not provide the states with clear notice, the condition is impermissible. Also, the Clawback Provision seems to be the kind of new programmatic requirement that Pennhurst prohibited and that Justice Ginsburg deemed improper in Arlington. If it is a new programmatic element, then the Clawback Provision, as a condition on federal spending, is impermissible whether one takes the majority view or the Ginsburg view of Pennhurst's precedential value in Arlington. The Clawback Provision itself is ambiguous in making the states wait for a payment total each year. Given that the states stand to lose all Medicaid funds if they do not pay pursuant to the Clawback Provision, it also implicates the germaneness and the coercion prongs of Dole, which have been largely ignored but should be re-examined. Sliced many different ways, the Clawback Provision appears to be unconstitutional.

\section{CONCLUSION}

A circuit split regarding statutory interpretation led to a constitutional decision that may be a benchmark in the Supreme Court's Spending Clause jurisprudence. Arlington has placed a new spin on one of the two Dole factors that is actively enforced by the Supreme Court. The "clear notice" required of conditional federal spending may have significant implications for federal healthcare programs.

As an example, this Article considered the Clawback Provision, a shifting of drug benefit responsibility for dual eligibles from Medicaid to Medicare that requires states to pay the federal government as a "condition" of Medicaid funding. If the Clawback Provision is a condition on federal spending for states' Medicaid programs (which appears to have been Congress's intent), then that controversial condition is unconstitutional under Arlington. The Clawback Provision also raises the question of whether the Court overreached in Arlington by discussing and altering spending power under Dole's second prong while still ignoring the possibility of coercing states.

Taking a broader view, because the Spending Clause is the foundation for many federal healthcare initiatives, a case that alters understanding of the conditions that can accompany federal spending is important for American healthcare in general. Arlington could affect much more than the one provision discussed herein; many Medicare and Medicaid statutory 
provisions have the potential to be deemed impermissible by virtue of failing to give clear notice to the states of such conditions. For example, the body of law that has developed regarding Medicaid healthcare providers' and enrollees' ability to enforce conditions of Medicaid funding against the states could be fundamentally altered by the Arlington decision and by the Roberts Court's willingness to revisit precedents that were considered long settled. ${ }^{261}$

The foundational Medicare and Medicaid statutes were enacted long before Arlington, and many amendments were enacted before Pennhurst when the only guidance for conditions on federal spending came from the limited analysis in United States v. Butler. ${ }^{262}$ Congress would not have thought it necessary to provide "clear notice" in passing laws that shape these federal spending programs, and yet the basic structure of the programs, particularly Medicaid, depends on cooperative federalism and Congress's power to place conditions on federal spending offered to the states. The implications of a new constitutional requirement such as Arlington's could be far reaching.

261. As Justice Breyer famously declared from the bench at the end of the second Roberts Court term: "It is not often in the law that so few have so quickly changed so much." Linda Greenhouse, In Steps Big and Small, Supreme Court Moved Right, N.Y. TIMES, July 1, 2007, at Al.

262. See supra notes $37-39$ and accompanying text. 